NBER WORKING PAPER SERIES

\title{
BEYOND MARKETS AND HIERARCHIES: \\ TOWARD A NEW SYNTHESIS OF AMERICAN BUSINESS HISTORY
}

\author{
Naomi R. Lamoreaux \\ Daniel M.G. Raff \\ Peter Temin
}

Working Paper 9029

http://www.nber.org/papers/w9029

\author{
NATIONAL BUREAU OF ECONOMIC RESEARCH \\ 1050 Massachusetts Avenue \\ Cambridge, MA 02138 \\ July 2002
}

Many colleagues have provided us with helpful criticisms and suggestions. We would especially like to express our appreciation to Ivan Berend, Ruth Bloch, Charles Calomiris, Sally Clarke, Patrick Fridenson, Louis Galambos, Oscar Gelderblom, David Kirsch, Christophe Lécuyer, Daniel Levinthal, Walter Licht, Ghislaine Lydon, Wallace Mullin, Eric Rasmusen, Jean-Laurent Rosenthal, Philip Scranton, Kenneth Sokoloff, Jonathan Steinberg, Stephen Usselman, Sidney Winter, and Mary Yeager. We would also like to thank participants in seminars and conference sessions at Cambridge University, Copenhagen University, Harvard University, the Norwegian School of Management (BI), the Stockholm School of Economics, the University of California, Los Angeles, the University of Pennsylvania, the University of Warwick, and annual meetings of the Business History Conference and the Economic History Association. Raff thanks the Reginald Jones Center at Wharton for financial support. The usual disclaimer applies. The views expressed herein are those of the authors and not necessarily those of the National Bureau of Economic Research.

(C) 2002 by Naomi R. Lamoreaux, Daniel M.G. Raff and Peter Temin. All rights reserved. Short sections of text, not to exceed two paragraphs, may be quoted without explicit permission provided that full credit, including (C) notice, is given to the source. 
Beyond Markets and Hierarchies:

Toward a New Synthesis of American Business History

Naomi R. Lamoreaux, Daniel M.G. Raff and Peter Temin

NBER Working Paper No. 9029

July 2002

JEL No. N0, M0, L2, D2

\begin{abstract}
We sketch a new synthesis of American business history to replace (and subsume) that put forward by Alfred D. Chandler, Jr., most famously in his book The Visible Hand (1977). We see the broader subject as the history of the institutions of coordination in the economy, with the management of information and the addressing of problems of informational asymmetries representing central problems for firm- and relationship design. Our analysis emphasizes the endogenous adoption of coordination mechanisms in the context of evolving but specific operating conditions and opportunities. This naturally gives rise both to change and to heterogeneity in the population of coordination mechanisms to be observed in use at any moment in time. In discussing the changes in the population of mechanisms over time, we seek to avoid the tendency, exemplified by Chandler's work but characteristic of the field, to see history of adoption in teleological rather than evolutionary perspective. We see a richer set of mechanisms in play than is conventional and a more complex historical process at work, in particular a process in which hierarchical institutions have both risen and, more recently, declined in significance.
\end{abstract}

Naomi R. Lamoreaux

Department of Economics

UCLA

Los Angeles, CA 90095-1477

and NBER

lamoreaux@econ.ucla.edu
Daniel M.G. Raff

Department of Management

The Wharton School

University of Pennsylvania

Philadelphia, PA 19104-6370

and NBER

raff@wharton.upenn.edu
Peter Temin

Department of Economics

MIT

Cambridge, MA 02142-1347

and NBER

ptemin@mit.edu 


\section{Beyond Markets and Hierarchies:}

\section{Toward a New Synthesis of American Business History}

In this essay, we offer a new synthesis of American business history to replace, but also to subsume, the dominant Chandlerian framework. ${ }^{1}$ Writing in the mid 1970s, Alfred D. Chandler, Jr., attributed the success of the U.S. economy in the twentieth century to the rise of large, vertically-integrated, managerially directed enterprises in the nation's most important industries. These enterprises, Chandler argued, were dramatically more efficient than the small, family owned and managed firms that had characterized the economy earlier. Small firms had to depend on the market to coordinate their purchases of raw materials and the sale of their output, but large firms took on these supply and marketing functions themselves, coordinating them internally by means of managerial hierarchies. This visible hand of management, Chandler claimed, was such a vast improvement over the invisible hand of the market that firms that exploited its capabilities were able not only to dominate their own industries but to diversify and attain positions of power in other sectors of the economy as well. ${ }^{2}$

A new synthesis is needed because these kinds of large-scale enterprises no longer look so superior from the perspective of the early twenty-first century. Indeed, as the economic environment changed during the 1980s and 1990s, classic Chandlerian firms increasingly found

\footnotetext{
${ }^{1}$ This effort at synthesis grows out of a series of conferences we organized at the National Bureau of Economic Research. For the revised proceedings, see Peter Temin, ed., Inside the Business Enterprise: Historical Perspectives on the Transformation and Use of Information (Chicago: University of Chicago Press, 1992); Naomi R. Lamoreaux and Daniel M. G. Raff, eds., Coordination and Information: Historical Perspectives on the Organization of Enterprise (Chicago: University of Chicago Press, 1995); and Naomi R. Lamoreaux, Daniel M. G. Raff, and Peter Temin, eds., Learning by Doing in Organizations, Markets, and Nations (Chicago: University of Chicago Press, 1999).

${ }^{2}$ See especially The Visible Hand: The Managerial Revolution in American Business (Cambridge: Harvard University Press, 1977); but also Scale and Scope: The Dynamics of Industrial Capitalism (Cambridge: Harvard University Press, 1990).
} 
themselves outperformed, even in their home industries, by smaller, more specialized, vertically disintegrated rivals. Many of the enterprises that now rose to the top succeeded by substituting for the visible hand of management alternative means of coordinating vertically and horizontally linked activities — most notably long-term relationships that were intriguingly similar to those that prevailed before the "rise of big business" or even before the so-called "market revolution." Large Chandlerian firms in turn sought to improve their competitiveness in this new environment by refocusing resources on their "core" businesses, selling off subsidiaries and even entire divisions and, in the process, reducing significantly the range of economic activity subject to managerial coordination.

At the very least, therefore, recent experience requires us to modify Chandler's framework so that we can explain why large vertically integrated, diversified enterprises did not perform as well under late twentieth-century conditions as they did earlier on. Our synthesis aims to do more, however. It aims to provide an alternative methodology for writing business history that avoids the tendency (exemplified by Chandler but also generally characteristic of the field) to view the present as the final stage in an evolutionary process and thus, effectively, the endpoint of history. ${ }^{3}$ With this goal in mind, we move beyond the simple markets versus hierarchies model that underpins Chandler's analysis to focus attention on the broad range of techniques that business people have developed over time to coordinate their activities. Using recent economic theory to array these mechanisms along a one-dimensional analytical scale, we offer some generalizations about their relative advantages and disadvantages under different sorts of circumstances. We then describe the uses to which these devices have been put over the

\footnotetext{
${ }^{3}$ This method for avoiding teleology is one of the most important features (in addition, of course, to substantive differences in interpretation) that distinguishes our synthesis from alternatives that see the economy of the 1990 s to be the last stage in a historical evolution. See, for example, Richard N. Langlois, "The Vanishing Hand: The Changing Dynamics of Industrial Capitalism," unpublished paper, 2001.
} 
course of American history, emphasizing both the diversity of the mechanisms in operation at any given point in time and the heterogeneity of the ways in which people with different kinds of businesses and experiences have adjusted their practices to changing economic circumstances.

There appears in hindsight to have been a clear economic logic to the pattern of successful and unsuccessful responses, yet in fact there was nothing predetermined about these outcomes. The advantage of our focus on heterogeneity — on the multiplicity of ways in which businesses have responded to change - is that it enables us to maintain a dual perspective whereby we can both elucidate the economic logic of the choices and, at the same time, regain a sense their contingency. In the end, this dual perspective will allow us not only to explain why Chandlerian enterprises suffered declining fortunes in the late twentieth century, but also to situate the "new-economy" firms of that period in the broad sweep of history-a history whose patterns can be understood retrospectively, but which also is still unfolding in ways that are by no means clear.

\section{The Chandlerian Synthesis and Our Alternative Approach}

Chandler's starting point was the observation that technological change had made it possible for firms to reap substantial economies of scale in a number of key industries by the late nineteenth century. His main intellectual contribution was to recognize that, in order to achieve the lower unit costs that technical economies of scale made possible, firms had to do a lot more than simply build large plants. They had to be able to maintain a high rate of throughput through their factories - that is, to keep their plants operating consistently at high levels of capacity utilization. In order to maintain a high rate of throughput, firms had to insure that shortfalls in supply did not disrupt their production processes and that output did not pile up in their 
warehouses unsold. The solution, as Chandler saw it, was for firms to bring these activities under their direct control by integrating backward into raw-material production and forward into distribution, and by building a managerial hierarchy capable of coordinating smoothly the flow of inputs and outputs from raw material to final sale. ${ }^{4}$

Chandler claimed that firms that took these steps improved upon the workings of the market, captured the resulting efficiency gains, and reaped enormous competitive advantages. The only firms that could compete with them head to head, he argued, were those that completely duplicated their vertically integrated structures and managerial hierarchies. Because relatively few firms could raise the enormous amounts of capital required, these kinds of industries quickly took on oligopolistic structures. Moreover, because large firms could exploit economies of scope as well as of scale by diversifying their operations into other industries, over time larger and larger portions of the economy became subject to their managerial authority. ${ }^{5}$

When The Visible Hand was first published in 1977, Chandler's synthesis represented an extraordinary achievement. It provided a respectable alternative to the robber-baron view of big business that still figured prominently in the literature. It also offered business historians for the first time a framework that made sense of the many (often antiquarian) histories of individual firms and industries that to that point largely constituted the field. Most significantly, it focused attention on a central economic problem — understanding the changes that had occurred over time in the way the provisioning of goods and services was organized — and drew out the implications of these changes for the structure of the American economy and for the place of the United States in the world.

\footnotetext{
${ }^{4}$ See The Visible Hand.

${ }^{5}$ Chandler, The Visible Hand; and Scale and Scope.
} 
Chandler's achievement was largely descriptive, however. Chandler never provided a clear theoretical rationale for his claim that the visible hand of management was more efficient than the invisible hand of the market in coordinating the flow of output in industries characterized by economies of scale. Rather, he based his account largely on the observation (derived from his voluminous reading of the literature on individual industries and firms) that vertically integrated, managerially directed enterprises had come by the early twentieth century to dominate these kinds of industries but generally not others. This lack of theory prevented Chandler from considering systematically other possible explanations for the dominance of large firms - for example, the role potentially played by barriers to entry that did not derive from superior organizational efficiency. ${ }^{6}$ More important for our purposes, the lack of theory made it very difficult for Chandler to explain the erosion that occurred in the position of these giant firms during the late twentieth century. ${ }^{7}$

After Chandler published The Visible Hand, other scholars jumped in to supply the missing theoretical rationale. The most notable among these was Oliver Williamson. Following a trail blazed initially by Ronald Coase, Williamson deliberately broke with the neoclassical view that firms' main function was to equate marginal revenue and marginal cost, postulating instead that firms were fundamentally devices to reduce transaction costs. ${ }^{8}$ Transaction costs arise, Williamson argues, because economic actors have only imperfect information to guide their behavior and because the information they possess is often asymmetric — that is, people

\footnotetext{
${ }^{6}$ On this point, see Naomi R. Lamoreaux, The Great Merger Movement in American Business, $1895-1904$ (New York: Cambridge University Press, 1985), pp. 118-86.

${ }^{7}$ In his one serious (but again essentially descriptive) attempt to confront this problem, Chandler argued that some large firms made the mistake of overdiversifying during the 1960s and 1970s and that their subsequent problems were a necessary correction. See Alfred D. Chandler, Jr., "The Competitive Performance of U.S. Industrial Enterprises since the Second World War," Business History Review, 68 (Spring 1994), pp. 1-72.

${ }^{8}$ Coase's seminal paper was "The Nature of the Firm," Economica, 4 (Nov. 1937), pp. 386-405. For Williamson's analysis, see Markets and Hierarchies: Analysis and Antitrust Implications: A Study of the Economics
} 
know more about their own attributes and actions than they know about those of others with whom they interact. The existence of such asymmetries makes it possible for economic actors to take advantage of one another when they exchange goods or services - that is, to extract more income from a transaction than they would receive if all the parties had full information. Moreover, this possibility is important because the fear that one party may use his or her informational advantage to exploit another may severely restrict the scope of exchange or even completely prevent business people from entering into otherwise mutually advantageous economic relationships. ${ }^{9}$

Williamson's goal was to understand how business activities could be organized to reduce the risk of exploitation and encourage economically productive relationships to be formed. In his view, the modern corporation (by which he meant the Chandlerian firm) was the "product of a series of organizational innovations that have had the purpose and effect of economizing on transaction costs." ${ }^{10}$ For example, firms learned to integrate backward to solve the problem of "asset specificity," the case where a supplier to a firm had to make investments that were highly specific to the transaction. Because the resulting assets could not be used easily for other purposes, the supplier was susceptible to "hold up"favorable contract terms once the investment was sunk - and, therefore, was unlikely to make the investment unless this possibility could be prevented. ${ }^{11}$ Because it was extremely difficult to

of Internal Organization (New York: Free Press, 1985); and The Economic Institutions of Capitalism (New York: Free Press-Macmillan, 1995).

${ }^{9}$ For a cogent example, see George Akerlof, "The Market for 'Lemons': Quality Uncertainty and the Market Mechanism," Quarterly Journal of Economics 85 (Aug. 1970), pp. 488-500. The 2001 Nobel Prize in Economics was awarded for this and other pioneering work along these lines.

${ }^{10}$ See Williamson, "The Modern Corporation: Origins, Evolution, Attributes," Journal of Economic Literature, 19 (Dec. 1981), pp. 1537-68. The quotation is from p. 1537. Chandler responded ambivalently to Williamson's reformulation of his narrative along transactions-cost lines, encouraging his efforts but in the end remaining aloof.

${ }^{11}$ See also Benjamin Klein, R.A. Crawford, and Armen Alchian, "Vertical Integration, Appropriable Rents, and the Competitive Contracting Process," Journal of Law and Economics, 21 (October 1978), pp. $297-326$. 
write ordinary contracts that would eliminate this risk, Williamson argued, the solution was for the firm to make the investment itself. Similarly, forward integration, Williamson hypothesized, was a solution to the "externality principle" - the possibility that the actions of one distributor might affect the ability of others to sell a good. If a distributor's poor record in installing or servicing a product could negatively affect the reputation of the product in consumers' eyes, then distributors would be reluctant to make the investments necessary to market the product properly, and manufacturers therefore would have to take on this function themselves.

Because Williamson's theory implies that the vertically integrated managerial enterprise always should be superior to alternative forms of contracting in industries where problems such as "asset specificity" and the "externality principal" arise, it would seem to be no more able than Chandler's account to explain recent shifts in such industries away from vertical integration. In fact, however, Williamson's theoretical reformulation of Chandler's narrative is an improvement because it allows for the possibility that environmental changes can affect the level of the transaction costs associated with, and thus the relative advantages and disadvantages of, different kinds of economic arrangements. Moreover, there is nothing in Williamson's transaction-cost theory that prevents one from moving beyond the dichotomous markets versus hierarchies approach that structured both his and Chandler's work to consider alternative ways of organizing business activity using essentially the same analytical framework. ${ }^{12}$

In the analysis that follows, we retain Williamson's core assumption that imperfect information gives rise to problems of exploitation whenever people attempt to exchange goods or services with each other — that is, to transact — but argue that economic actors have attempted to

\footnotetext{
12 Indeed, in "Comparative Economic Organization: The Analysis of Discrete Structural Alternatives," Williamson modified his markets versus hierarchies approach to include intermediate forms of organization that he called "hybrids." Administrative Science Quarterly, 36 (June 1991), pp. 269-96.
} 
resolve these kinds of problems in a wide variety of ways. For simplicity, we present these efforts to coordinate economic activity as mechanisms arrayed along a one-dimensional scale according to the permanence of the resulting relationships between the transacting parties. At one extreme of the scale lies pure market exchange - that is, transactions that are discrete in the sense that there is no ongoing connection between the parties involved. At the other extreme is pure hierarchy — a permanent, or at least very long-lived, command relationship in which superiors issue orders to subordinates (obvious examples include rank-and-file soldiers and slaves), who face draconian punishment for non-compliance. In the middle are long-term relationships among otherwise independent economic actors - an intermediate form important enough to be identified as a third major type of coordination mechanism.

It is important to realize none of these ideal types of coordination mechanisms works perfectly. Each one does certain things (and not others) well. Moreover, there are circumstances under which these relative advantages will be undermined by imperfect information. This point can be seen most clearly by focusing on the extremes of our one-dimensional scale. For example, the benefits of arms-length (market) transactions as a form of coordination lie chiefly in their ability to minimize costs. Under conditions of imperfect information, however, some buyers (for instance, those located far away) may not be able to ascertain the quality of the goods being sold; and hence a seller may be able to foist a good on a buyer that is of lower than contracted quality. The more complex the good, the more likely this problem. Because there is no expectation of a repeat interaction in this pure-market setting, there is no way for a buyer to punish such behavior by refusing to deal with the seller again. ${ }^{13}$ For similar reasons, a buyer cannot punish a supplier who fails to deliver goods in a timely fashion (perhaps because he chose

\footnotetext{
${ }^{13}$ For the famous example, see Akerlof, "The Market for 'Lemons."”
} 
to fulfill a more remunerative contract first) or even determine reliably whether the supplier in fact misbehaved or simply experienced unavoidable delays. ${ }^{14}$

The advantage of hierarchical control lies in its potential to eliminate these kinds of problems by internalizing and more firmly controlling the transactions so that the quality of goods and the timing of their delivery can be adjusted to meet the firm's needs. For hierarchies to work well as coordination mechanisms, however, the directives issued by superiors must be obeyed. The problem is that subordinates may follow only those orders that they perceive to be in their own interests, or in the interests of their part of the organization, and ignore other instructions. Or they may have different ideas about what to do. If the organization is large or if the contributions of individual workers are difficult to disentangle from those of other employees, superiors may have only imperfect knowledge of what their subordinates are doing and may not be able to detect and punish such deviations. Subordinates, therefore, may be able to exploit this "principal-agent" problem to engage in behaviors that are contrary to the wishes of their superiors. ${ }^{15}$

Particular coordination mechanisms can sometimes be made more effective by combining them with other mechanisms from different parts of the spectrum. Hence problems of asymmetric information in markets can be reduced by adding elements of hierarchy (for example, by creating a regulatory authority to oversee the exchange), and problems in hierarchies can be reduced by adding elements of market competition (as, for example, when

\footnotetext{
${ }^{14}$ For a related example, see Thomas N. Hubbard, "Contractual Form and Market Thickness in Trucking," Rand Journal of Economics, 32 (Summer 2001), pp. 369-86.

${ }^{15}$ For the germ of this idea, see Herbert Simon, "A Formal Theory of the Employment Relationship," Econometrica, 19 (July 1951), pp. 293-305. For a more extensive discussion, see J. W. Pratt and R. Zeckhauser, eds., Principals and Agents (Boston: Harvard Business School Press, 1985). Even organizations as highly disciplined as the military can be affected by such problems, as is suggested by Wellington's lament that "nobody in the British Army ever reads a regulation or an order as if it were to be a guide for his conduct, or in any manner other than as an amusing novel." Quoted in Elie Halévy, England in 1815 (New York: Barnes \& Noble, 1961), p.
} 
plant managers are evaluated according to their relative ability to reduce unit costs). Long-term relationships can also be used to improve the workings of markets and hierarchies. For example, in order to insure that goods are of desired quality, buyers may prefer to deal with suppliers with whom they have dealt satisfactorily in the past and with whom, therefore, they have been able to establish relations of trust. These relationships may prove so valuable that buyers may prefer to continue to purchase from these suppliers even when it is possible to get goods on the spot market more cheaply, and sellers will go to great lengths to maintain their reputations for quality, even when it is costly to do so. Similarly, superiors in hierarchies may find (as executives of many large firms have discovered in recent years) that certain kinds of economic activities are better coordinated outside the firm—not by spot markets but by means of long-term relationships in which the need to build and maintain trust disciplines the parties' behavior to their mutual benefit. Of course, long-term relationships are no more immune to information problems than markets or hierarchies. Hence they too are often combined with elements of one or the other of these two extreme forms in order, for example, to prevent one party in a relationship from taking advantage of another or to enable the terms of relationship to change in response to economic needs.

The extent to which particular coordination mechanisms (or combinations thereof) effectively solve problems of asymmetric information also depends on the institutional environment, which (following Douglass North) we define broadly to include not only formal rules (such as laws) and the procedures to enforce them, but also moral and ethical norms. ${ }^{16}$ Thus markets, and also long-term relationships, may work better in situations where buyers and

85. $201-2$.

${ }^{16}$ Douglass C. North, Structure and Change in Economic History (New York: W. W. Norton, 1981), pp. 
sellers are members of the same religious group and believe that God will punish them if they cheat each other. Similarly, subordinates in hierarchies may be more likely to respond obediently to instructions if the authority of their superiors is legitimated by broader cultural values, whether they be meritocratic or ascriptive. In addition, the extent to which the legal system efficiently punishes violations of contract can affect the utility of markets relative to long-term relationships (or hierarchies), which can be thought of as substitutes for effective contract enforcement. ${ }^{17}$

Coordination mechanisms that successfully mitigate problems of asymmetric information in one period may not operate effectively in the next if economic conditions or the institutional environment changes. Under such circumstances, economic actors may be forced to alter the way they do business in the face of a great deal of uncertainty about the kinds of solutions that are likely to work. Some will innovate - that is, experiment creatively with entirely new types of solutions. Others will imitate arrangements that seem to be working for others or try out ideas that are "in the air." Regardless, their search for workable solutions to the new information problems they face will proceed in a manner that is more like Herbert Simon's concept of "satisficing" than a standard neoclassical optimization calculus — that is, confronted with a problem, they will try out responses until they find something that seems to work adequately and then stop. ${ }^{18}$ Moreover, because it is difficult to remake completely existing organizations and relationships, the solutions that economic actors adopt will be affected to some extent by what they have done in the past. The search for more effective coordination mechanisms, in other

\footnotetext{
${ }^{17}$ See, for example, Avner Greif, "Self-Enforcing Systems and Economic Growth: Late Medieval Genoa," in Analytic Narratives, eds. Robert H. Bates, et al. (Princeton: Princeton University Press, 1998), pp. 23-63; and "Cultural Beliefs and the Organization of Society: A Historical and Theoretical Reflection on Collectivist and Individualist Societies," in The New Institutionalism in Sociology, eds. Mary C. Brinton and Victor Nee (New York: Russell Sage Foundation, 1998), pp. 77-104.

${ }^{18}$ See, in particular, Simon's Models of Man: Mathematical Essays on Rational Human Behavior in a
} 
words, will be path dependent in the sense that the choices that business people make are likely to be affected by the ways they organized their activities previously and also by the particular range of options conspicuously available to them at that point in history. ${ }^{19}$

\section{The Setting}

Because starting points affect the ways in which economic processes unfold, we begin with a survey of the main coordination mechanisms in place at the beginning of the nineteenth century - that is, before dramatically falling transportation and communication costs forced business people to develop new ways of coordinating their activities. Most exchange at this time was necessarily local. In 1800, only about six percent of the nation's approximately five million people resided in urban areas, and 60 percent of these lived in towns with less than 25,000 residents. ${ }^{20}$ The vast majority of the population was spread thinly across the rapidly expanding countryside, organized into households that functioned as the economy's main production units.

Production within households was coordinated hierarchically, although there was also a division of labor along gender lines. The father was the head of the family and, as such, was responsible for training and disciplining children, especially sons, and assigning them tasks. The father represented the family's interests in the outside world, marketing most of its output and purchasing supplies that it could not produce for itself. He also controlled the distribution of the family's income and wealth and had full property rights to the labor of his minor children.

Social Setting (New York: Wiley, 1957), pp. 196-206, 241-60.

${ }^{19}$ As this language suggests, our approach owes much to the work of Richard R. Nelson and Sidney G. Winter. See especially An Evolutionary Theory of Economic Change (Cambridge: Harvard University Press, 1982). See also Paul David, "Why Are Institutions the 'Carriers of History'?: Path Dependence and the Evolution of Conventions, Organizations and Institutions," Structural Change and Economic Dynamics, 5 (Dec. 1994), pp. 20520 .

${ }^{20}$ U.S. Census Bureau, Historical Statistics of the United States on CD-ROM: Colonial Times to 1970Bicentennial Edition (New York: Cambridge University Press, 1997), Series A57-72. 
Indeed, he could sell this labor to others if he did not wish to exploit it himself. Because the father spent most of his time in the household, he could easily detect and punish disobedience.

Sometimes a child ran away to escape the father's authority, but more often there were significant rewards to be earned by staying in the household and obeying the father. In addition, the affective bonds that formed between parents and children mitigated (and, of course, also reinforced) the hierarchical nature of patriarchal authority. ${ }^{21}$

The mother functioned as the father's second in command. She was supposed to be subservient to his wishes whenever he was present, but had to be able to substitute for him and run the family enterprise in his absence. The mother also managed her own domain, which might include home manufactures and involve both supervising girls in various production tasks and dealing independently with outside suppliers and purchasers. In the Ballard family of Hallowell, Maine, for example, the husband, Ephraim, took charge of farm production and other enterprises such as saw milling. The wife, Martha, was a midwife, and in addition to her extensive medical practice, directed her daughters (and the other young girls who were sent from time to time to live and work with them) in the home production of textiles and other goods. ${ }^{22}$

Economic activity within shops and stores was an extension of that within families. As a result, these enterprises could exploit the family's gendered division of labor. In the early shoe industry, for example, masters' wives provided board and other household services for apprentices and journeymen and also engaged in the production of goods that contributed directly to the business, for example, spinning flax into the linen thread that the men needed to

\footnotetext{
${ }^{21}$ For an example of a father who exercised his property right by selling his son's labor, see David Crockett, A Narrative of the Life of David Crockett of the State of Tennessee (Lincoln: University of Nebraska Press, 1987). The narrative was originally published in 1834. More generally, see Robert A. Pollak, "A Transaction Cost Approach to Families and Households," Journal of Economic Literature, 23 (June 1985), pp. 581-608.

${ }^{22}$ Laurel Thatcher Ulrich, A Midwife's Tale: The Life of Martha Ballard, Based on her Diary, 1785-1812 (New York: Alfred A. Knopf, 1990); and Ulrich, Good Wives: Image and Reality in the Lives of Women in
} 
sew shoes. Moreover, women gradually took on other production tasks as well, most notably the job of "shoebinding" - that is, sewing together the leather "uppers" of the shoe. They performed these new functions in the same way as other household tasks, working in their kitchens and interspersing their work on shoes with child-rearing and other domestic responsibilities. ${ }^{23}$

Apprentices, journeymen, and clerks typically lived in the master's household and were subject to his discipline in the same way as children were. Their incentive to obey was somewhat different, however, as it depended on the future rewards to be earned by accumulating skill or knowledge in the business and the extent to which a good relationship with the master might help the young man get a start in his field. Clerks, for example, often moved into positions as junior partners after a period of training, and thus had a powerful motive to stay on their master's good side. In occupations where these kinds of future rewards were meager, where the amount of training required for technical mastery was modest, or where young men had other opportunities that did not require such a lengthy period of training, apprentices tended to run away. Thus in industries where technological change during the early nineteenth century reduced skill requirements, apprenticeship tended to decline and a more impersonal labor market to develop. ${ }^{24}$

Although activity within households, shops, and stores was generally coordinated hierarchically, interactions among these various economic units were more typically mediated by long-term relationships. When farmers did business with local storekeepers and craftsmen, they

Northern New England, 1650-1750 (New York: Alfred A. Knopf, 1982).

${ }^{23}$ Mary H. Blewett, Men, Women, and Work: Class, Gender, and Protest in the New England Shoe Industry, 1780-1910 (Urbana: University of Illinois Press, 1990), pp. 3-19.

${ }^{24}$ Gillian Hamilton, "Enforcement in Apprenticeship Contracts: Were Runaways a Serious Problem? Evidence from Montreal," Journal of Economic History, 55 (Sept. 1995), pp. 551-74; Bernard Elbaum, "Why Apprenticeship Persisted in Britain but not in the United States," Journal of Economic History, 49 (June 1989), pp. 337-49; W. J. Rorabaugh, The Craft Apprentice: From Franklin to the Machine Age in America (New York: Oxford University Press, 1986); and Tristan Traviolia, "White Male Apprenticeship in the Early Republic," unpublished 
dealt with kinsmen or neighbors with whom they had close multidimensional relationships. The need to deal with each other repeatedly in a number of different contexts discouraged one party from taking advantage of another. In addition, a variety of customary practices governed these local transactions. When cash was not available, for example, payment took the form of book debt, which did not bear interest charges and was likely to be paid off over a long time horizon through offsetting book credits. These credits might result from goods provided or services performed by the borrower himself or they might derive from exchange with third parties (also typically from the same local network) who were indebted on the borrower's books. Borrowers were socially obligated to pay off their debts, but lenders similarly were obligated not to pressure those who owed them for goods. ${ }^{25}$

Farmers periodically traveled to more distant markets to sell their output and buy manufactured goods and other commodities. In the course of these journeys, they learned about the prices their goods commanded in regional and even international markets, information that then affected the terms under which they were willing to engage in local exchange. As Winifred Rothenberg has shown for late-eighteenth-century Massachusetts, prices in different towns tended to converge and to exhibit similar movements over time. ${ }^{26}$ Although exchange was still primarily local and governed by customary practices and personal relationships, there was still some danger that buyers would try to pay too little or sellers charge too much for goods. The

paper, 2000 .

${ }^{25}$ Christopher Clark, The Roots of Rural Capitalism: Western Massachusetts, 1780-1860 (Ithaca, NY: Cornell University Press, 1990), pp. 21-38. These social conventions might break down, however, during periods of severe economic strain. For an example, see Thomas Stuart Allen, "Commerce, Credit and Community: The Transformation of Economic Relationships in Rhode Island, 1771-1850," unpub. Ph.D. diss., Brown University, 1994, pp. 101-2.

${ }^{26}$ Winifred Barr Rothenberg, From Market-Places to a Market Economy: The Transformation of Rural Massachusetts, 1750-1850 (Chicago: University of Chicago Press, 1992), pp. 80-111. 
market provided a source of information that limited the extent to which such behavior could occur.

Households bought most goods that they could not produce for themselves from local shopkeepers and artisans, but some of these products (mainly manufactures and agricultural commodities that could only be grown in other climates) came from far away. This longdistance exchange was facilitated by networks built up by merchants in port cities—networks that incorporated both storekeepers in the countryside and merchants in other ports throughout the trading world. Because trade over long distances posed difficult principal-agent problems when transportation and communication costs were high, the earliest links among merchants in different locations were mainly familial. For example, a member of a trading family would journey to a distant port and there commence business on the family's account. Agents who were family members were less likely to pursue their own interests at the expense of their principals because they would not want to risk their claim on familial resources. Other kinds of personal connections could also provide a basis for the creation of long-distance trading relationships. Members of minority religious groups, such as the Quakers, had duties toward coreligionists, even if they were otherwise strangers, that they did not have toward people of other faiths. Moreover, connections could be built up over time through letters of introduction and repeat dealing. A merchant might trust a colleague in another location who had been recommended to him for a small amount, and if the outcome was within expectations, continue the relationship, gradually expanding both the amount and type of business transacted. The resulting business "friendship" brought with it social expectations that were in many ways 
similar to those between kinsmen and neighbors and helped to insure that the relationship would proceed according to terms acceptable to both parties. ${ }^{27}$

Merchants who invested in factories during the early part of this period exploited these trading networks both to sell output and to process intermediate goods using the putting-out system. A good example is Almy \& Brown, the enterprise that combined the technical expertise of British mechanic Samuel Slater with the commercial know-how of Providence merchant Moses Brown to establish the first successful cotton-spinning mill in the United States in 1790. Almy \& Brown sold some of their machine-spun thread on the market, making use of trading connections that the Brown family had painstakingly built up over the previous half century, but they consumed much of it as an intermediate good in the production of cotton cloth, which they also sold through their trading network. Almy \& Brown initially had employed a number of handloom weavers in their factory, but they were not able to concentrate enough workers in one place to absorb the output of their spinning machines. Very quickly they shifted their energies into transforming the rural shopkeepers with whom they had long done business into intermediaries who would distribute their thread to farm households to be woven into cloth. But the enormous coordination problems that this system entailed (just to mention one, unsupervised workers weaving in their homes turned out fabrics of vastly varying qualities) spurred

\footnotetext{
${ }^{27}$ Bernard Bailyn, The New England Merchants in the Seventeenth Century (New York: Harper Torchbooks-Harper \& Row, 1955); David Hancock, Citizens of the World: London Merchants and the Integration of the British Atlantic Community, 1735-1785 (Cambridge: Cambridge University Press, 1995); Thomas M. Doerflinger, A Vigorous Spirit of Enterprise: Merchants and Economic Development in Revolutionary Philadelphia ((New York: W.W. Norton, 1986), pp. 47-62; T. H. Breen, Tobacco Culture: The Mentality of the Great Tidewater Planters on the Eve of Revolution (Princeton: Princeton University Press, 1985), pp. 84-123. For a more general theoretical treatment, see Pollak, "A Transaction Cost Approach"; and Yoram Ben-Porath, "The F-Connection: Families, Friends, and Firms and the Organization of Exchange," Population and Development Review, 6 (Mar. 1980), pp. 1-30.
} 
manufacturers to reconcentrate production in factories as soon as technological innovation in the form of the power loom enabled them to expand capacity sufficiently. ${ }^{28}$

Within their factories, Almy \& Brown, Slater, and other early textile manufacturers who followed their example initially attempted to coordinate their workers using traditional patriarchal means of control. Their labor forces consisted for the most part of the children and unmarried daughters of local farmers, and Slater in particular recognized the value of the father's authority over his dependents. Before the 1830s, he rarely employed children who were not subject to the discipline of a local household, and insisted on negotiating their labor contracts with (and paying the children's wages to) household heads, who obligated themselves to provide Slater with an agreed upon supply of workers, promised to find substitutes if their children could not go into the mill, and undertook to insure that their children worked diligently. This strategy ultimately proved unworkable, however, for fathers often had different ideas from factory owners about what their children should do in the factory and how hard and long they should work. $^{29}$

The much larger textile factories built during the second and third decades of the nineteenth century by Francis C. Lowell, Nathan Appleton, and others collectively known as the Boston Associates, used a very different labor system. Because they needed many more workers than could be obtained from local farm households, they had to convince young, unmarried women from all over New England to come work temporarily in the mills. In order to make

${ }^{28}$ Barbara M. Tucker, Samuel Slater and the Origins of the American Textile Industry, 1790-1860 (Ithaca, NY: Cornell University Press, 1984), pp. 57-8, 104-5; Alison Wheeler, "The Forces of Industrialization and the Blackstone Manufacturing Company, 1808-1864," Senior Honors Thesis, Brown University, 1991; Thomas Dublin, Transforming Women's Work: New England Lives in the Industrial Revolution (Ithaca: Cornell University Press, 1994), pp. 37-48. For a theoretical treatment of the shift from putting-out to factory production, see Joel Mokyr, "The Rise and Fall of the Factory System: Technology, Firms, and Households Since the Industrial Revolution," unpublished paper, 2000.

${ }^{29}$ Tucker, Samuel Slater, pp. 147-162; Teresa Anne Murphy, Ten Hours'Labor: Religion, Reform, and 
factory employment more attractive to this group, they invested in boarding houses and educational institutions. They eschewed the traditional coordination mechanisms of the Slatertype mills and contracted directly with their female employees, paying them wages on their own account. Although sometimes the women dutifully turned their earnings over to their families, often they retained control of the money they earned and chose how to allocate it themselveshow much to save, how much to consume, and what to consume it on. ${ }^{30}$

The difficulties involved in coordinating such sizeable factory labor forces encouraged manufacturers to invest in religious institutions that would inculcate in their workers the values of hard work and responsibility. ${ }^{31}$ They also spurred managers to develop new information systems that would enable them to monitor (and hence control) their workers' activities. Merchants involved in the putting out system had used traditional commercial accounting systems designed to keep track of debits and credits, and these methods were employed by early manufacturers as well. Very quickly, however, the managers of larger enterprises devised new systems of accounts to keep track of their labor costs. For example, Lowell-type textile mills generated production-expense reports that mainly concerned labor and were used to evaluate the efforts both of individual workers and of those who supervised them. In addition, they adapted to the new factory environment the putting-out custom of paying by the piece, creating an incentive for operatives to tend their machines diligently by making their income proportional to

Gender in Early New England (Ithaca: Cornell University Press, 1992), pp. 9-31.

${ }^{30}$ Thomas Dublin, Women at Work: The Transformation of Work and Community in Lowell, Massachusetts, 1826-1860 (New York: Columbia University Press, 1979), pp. 23-57.

${ }^{31}$ Indeed, some scholars have argued that manufacturers encouraged the spread of evangelical Protestantism during this period in order to increase the discipline of their workforces. See, for example, Anthony F. C. Wallace, Rockdale: The Growth of an American Village in the Early Industrial Revolution (New York: W. W. Norton, 1971), pp. 296-471; Tucker, Samuel Slater, pp. 163-185; and Judith A. McGaw, Most Wonderful Machine: Mechanization and Social Change in Berkshire Paper Making, 1801-1885 (Princeton: Princeton University Press, 1987), pp. 81-88. Other scholars, however, have argued that religion could also play a subversive role. See Murphy, Ten Hours' Labor, pp. 73-100. 
output. $^{32}$

Even though transportation and communication systems were primitive at the beginning of the nineteenth century, the rural economy was productive and farmers relatively prosperous. Local shopkeepers stocked goods (supplied by merchants in port cities) for which there was a predictably steady demand-for example, the machine-made textiles that British and later New England factories were turning out increasingly cheaply. But shopkeepers could not afford to maintain inventories of goods, particularly expensive durable goods, for which there was only sporadic local demand, and this inability created an incentive for merchants to find new ways of tapping farmers' buying potential. One important innovation was to hire as peddlers young men eager to escape the drudgery of farming and send them wandering through the countryside loaded down with merchandise.

Two lessons quickly became apparent from this innovation. The first was that there was indeed a broad rural market for consumer durables like clocks, if such items could be produced at a cost that brought them within range of the "middling sort" of farmer. Connecticut merchants Levi and Edward Porter attempted to follow up on this lesson by contracting in 1807 with clockmaker Eli Terry for the production of 4,000 inexpensive, wooden-movement clocks in three years' time. In order to fill this contract Terry had to learn how to simplify the clock's mechanisms and develop special purpose machinery to produce the component parts. He spent the first year of the contract designing and building machinery, made 1000 clocks the second year, simplified his clock design further, and made 3000 clocks the third year of the contract. Until this point, no clockmaker could have made this many clocks in a lifetime, let alone in a

\footnotetext{
${ }^{32}$ Steven Lubar, "Managerial Structure and Technological Style: The Lowell Mills, 1821-1880," Business and Economic History, Second Series, 13 (1984), pp. 20-30; H. Thomas Johnson, "Early Cost Accounting for Internal Management Control: Lyman Mills in the 1850's," Business History Review, 46 (Winter 1972), pp. 466474; Dublin, Women at Work, p. 66. These innovations appear to have been adopted by Slater-type mills during the
} 
single year. Thus the ability to distribute goods to a broad market of farmers stimulated technological change in the direction of the "American system" of mass-production-that is, the use of special-purpose machinery to produce components that could be relatively easily assembled into a finished good. ${ }^{33}$

The second lesson that merchants learned from their experience with peddlers was that there were serious agency problems associated with this means of distribution. Merchants had no way of insuring that the peddlers they hired would treat expensive and delicate merchandize like clocks with suitable care or that they would report accurately the prices at which they sold their merchandise to farmers. Similarly, farmers whose experience with manufactured goods was relatively limited had good reason to suspect that peddlers, whom they were likely never to see again, would misrepresent the quality of their wares or overcharge them for items they wished to purchase. Not surprisingly, after one or two bad experiences farmers might greet traveling salesmen in the way that one did the young James Guild—with threats of violence if they did not leave their property immediately. ${ }^{34}$ The experience of peddlers thus illustrates the difficulties associated with marketing goods over long distances in an economy where transportation and communications costs were high. In the absence of networks based on family, religion, or long-term association, exchange was difficult to conduct.

\footnotetext{
1830s. See Tucker, Samuel Slater, pp. 153, 204-6, 228-9.

${ }_{33}$ Donald R. Hoke, Ingenious Yankees: The Rise of the American System of Manufactures in the Private Sector (New York: Columbia University Press, 1990).

${ }^{34}$ Guild quickly learned some of the tricks in trade of the Yankee peddler-for example, repackaging identical scissors so that they appeared to represent gradations in quality and playing upon farmwives' desires to buy superior merchandise. See "The Journal of James Guild," Proceedings of the Vermont Historical Society, New Series, V (Sept. 1937), pp. 249-314. For a general treatment, see Joseph T. Rainer, "The 'Sharper' Image: Yankee Peddlers, Southern Consumers, and the Market Revolution," Business and Economics History, 26 (Feb. 1997), pp. 27-44.
} 


\section{The Market Revolution}

By the middle of the nineteenth century, a series of transportation and communication innovations - first the steamboat and the canal and then the railroad and the telegraphdramatically reduced the cost of transacting over long distances. These improvements did not automatically effect a market revolution, however. In order for consumers to be willing to buy goods from producers located far away, business people had to develop new coordination mechanisms to solve the inevitable problems of asymmetric information. The best way to understand this point is to look at the example of a basic commodity like wheat.

During the antebellum period, farmers in the expanding agricultural regions of the Middle West shipped their wheat to market in essentially the same way that farmers everywhere had done for decades - that is, they packed it into sacks which then made the full journey from

production site to final market. ${ }^{35}$ Because each sack contained wheat from a particular farm, the name of which was preserved by the merchants who bought the grain, the identity of the farmer served as an assurance of the quality of the product. As Chicago's hinterlands expanded with the construction of the railroad network, however, the costs associated with handling an ever larger volume of shipments in this manner mounted, and merchants began to take wheat out of the sacks and pour it into grain elevators and railroad cars. The problem was that as grain from one farm became intermixed with, and indistinguishable from, grain from all the others, consumers had no way of determining in advance whether they were buying the quality of product they desired. The Chicago Board of Trade (the organization to which merchants involved in this business belonged) grappled with this problem during the 1850 s by dividing wheat into three 
categories — white winter wheat, red winter wheat, and spring wheat — and measuring the quantity of grain by weight rather than volume.

This remedy proved inadequate, however, because farmers no longer had any incentive to devote care and effort to cleaning their wheat. To the contrary, the incentive structure encouraged them to adulterate their wheat with cheaper grains or even with inedible materials that would increase its weight and hence the payment they received at market. The result was a general fall in the average price earned by the region's farmers. When the situation worsened during the hard times that followed the Panic of 1857, the Board of Trade responded by dividing the three categories of wheat into finer gradations based on quality (including "rejected" for wheat deemed too inferior to be marketed). Then, to convince buyers that the wheat they purchased would indeed be of advertised grade, the Board hired inspectors with the authority to enter storage elevators and make sure that merchants were adhering to the new standards — that is, it added an element of hierarchy to coordination by the market.

As the case of wheat suggests, broad geographic markets did not emerge automatically as a result of falling transportation and communication costs; rather they had to be actively created. In order for such markets to work effectively, the information problems associated with exchanging goods in quantity among actors physically remote from one another had to be solved. If the personal identity of the producer could no longer provide an assurance of quality, new ways of guaranteeing standards had to be designed. As the merchants of Chicago quickly learned, moreover, consumers would only accept these standards as informative if some person or group with something at stake stood behind them. The Chicago Board of Trade would have

${ }^{35}$ This example is drawn from William Cronon, Nature's Metropolis: Chicago and the Great West (New York: W.W. Norton, 1991), pp. 104-119. 
squandered a palpably valuable reputation if it had not devised administrative mechanisms adequate to insure that merchants adhered to its standards.

The techniques developed by the Chicago Board of Trade worked well for agricultural commodities that could relatively easily be sorted into standard grades. But the marketing of more complex goods to remote consumers required different methods. One solution was the emergence of large wholesaling firms. These enterprises functioned very differently from the merchants of the previous period. In the first place, they bypassed the networks of personal connections that earlier merchants had so painstakingly built up over time, and instead opened offices throughout the country, constructing their own internal networks of purchasing and sales agents. These they coordinated hierarchically, creating lines of authority radiating from a national office to regional and local offices whose managers were responsible for monitoring agents in their respective areas. More important, unlike earlier merchants who typically operated on a commission basis, the new national wholesalers took formal title to the goods they handled. Often they branded them with their own trademarks and, by thus putting their own reputations on the line, assumed responsibility for the quality of the goods they marketed. ${ }^{36}$

Consumers rarely bought goods directly from wholesalers but instead typically purchased their wares from the retailers who were the wholesalers' main customers. The growing concentration of population in cities during the late nineteenth century made it possible for urban retailers to expand and diversify their offerings. It was during this period that department stores, dime stores, and other types of mass retailers (the largest of whom were able to bypass wholesalers and create their own purchasing networks) began to provide urban residents with a cornucopia of goods at both cheaper prices and guaranteed quality. The buyers for these large

\footnotetext{
${ }^{36}$ Chandler, The Visible Hand, pp. 215-224.
} 
retailers took on the role, in Regina Blaszczyk's apt phrase, of "fashion intermediary" for the economy. ${ }^{37}$ It was their job to collect information about customers' tastes and communicate this knowledge to the wholesalers and manufacturers who supplied their stores. In this way, they helped to insure that manufacturers would make, and wholesalers would stock, the goods that consumers really wanted to buy. Moreover, because the business of these stores was so valuable, suppliers had good reason to meet the buyers' expectations about quality.

Tapping the consumption potential of America's large numbers of prosperous farmers depended on another innovation of the period - the catalog mail-order firm. First Montgomery Ward, and then Sears, Roebuck \& Company, took advantage of the new national railroad network to create a distribution system that supplanted the itinerant peddlers of the previous period. Having mailed rural Americans catalogs that listed a wide variety of merchandise, they took orders by return post, and then shipped the goods to purchasers with a money-back guarantee. As in the case of urban retailers, their buyers served the dual function of communicating information about consumers' tastes to suppliers and enforcing standards of quality.

Large wholesalers and retailers thus solved the problem of trading a large volume of goods over long distances by substituting hierarchical coordination for the networks and itinerant peddlers that earlier merchants had employed. Hierarchies, however, were no more likely to work automatically than markets were. These organizations too had to confront serious information problems in order to live up to the promises they made to consumers and still earn a profit sufficient to attract and retain investors. Sears, for example, had to redesign completely its distribution system. Initially the firm had goods shipped directly to consumers from the factories

\footnotetext{
${ }^{37}$ Regina Lee Baszczyk, Imagining Consumers: Design and Innovation from Wedgwood to Corning
} 
in which the goods were made. The products frequently arrived in damaged condition, and it was difficult for the company to determine the extent to which the factory had been responsible for the problem by packing merchandise improperly or even by shipping damaged goods. Factories, moreover, were often slow to process orders. They were supposed to report to Sears when and what they had shipped, but these messages too were often slow in coming. When a customer complained to Sears that a product had arrived damaged or had not arrived at all, Sears sent the factory another order to ship. In that age of handwritten ledger books, there was no easy way to check the new order against the records of outstanding older ones, and so orders frequently were sent out more than once. The cost to Sears of all these errors was large because Sears paid the freight for returns and because duplicate and damaged shipments affected consumers' perceptions of the company's competence. ${ }^{38}$

Sears dealt with these problems by expanding its activities to take on functions that hitherto had been the responsibility of its suppliers (that is, it integrated vertically). In 1906, it opened a massive new mail-order warehouse in Chicago. Henceforth the company would ship goods from this facility and not from the individual manufacturer. For this expensive investment to pay off, however, Sears had to confront its own internal principal-agent problems. To this end, Sears divided its warehouse into departments overseen by supervisors who were linked in a chain of command to top company officials. It also simultaneously created an incentive structure to keep departmental managers on their toes. When an order arrived, a clerk assigned it to an individual shipping room for a particular fifteen-minute period and directed each department responsible for supplying an item to deliver the good to that room in the allotted time. At the end

(Baltimore: Johns Hopkins University Press, 2000).

${ }^{38}$ Daniel M. G. Raff and Peter Temin, "Sears, Roebuck in the Twentieth Century: Competition, Complementarities, and the Problem of Wasting Assets," in Lamoreaux, Raff, and Temin, eds., Learning by Doing, pp. $221-5$. 
of the fifteen minutes, the goods were packaged together and shipped out. Items that did not arrive in time had to be shipped separately at the expense of the supplying department. This cost of late delivery motivated supplying departments to maintain adequate inventories and to organize them so they could find products quickly on demand. ${ }^{39}$

The growth of large-scale business enterprises also increased the principal-agent problems associated with the coordination of labor. It had been a relatively simple proposition to pay an employee in a small artisanal workshop, or even a laborer in a small factory, according to the value of his or her marginal revenue product. (Piece rates could be an effective way of gauging effort.) In large firms, however, the value of an individual worker's marginal product might be neither well defined nor easy to measure, improvements in accounting practice notwithstanding. Moreover, such knowledge as could be obtained by direct observation about the effort individual employees expended was often the property of foremen, who might not think that it was in their interests to transfer this knowledge in any complete fashion to superiors. Taylorism was in essence an attempt to bypass foremen, secure direct information about the effort it was reasonable to expect from workers on an ongoing basis, and create incentives for workers to fulfill expectations. It quickly became apparent, however, that in complex production situations that required team efforts, individual incentives could be counterproductive if employees did not respond by working at the same pace. Consequently, firms in industries with this characteristic tended to shift away from individual toward group incentives. ${ }^{40}$ Yet another

\footnotetext{
${ }^{39}$ Raff and Temin, "Sears, Roebuck in the Twentieth Century," pp. 221-5. Like these late charges, accounting systems could be used to improve the functioning of managerial hierarchies. For example, Andrew Carnegie developed sophisticated cost accounting techniques that not only allowed him to pinpoint inefficiencies in the production process but also to pit his plant managers against one other and thus use competitive pressures to make them function more effectively. See Harold C. Livesay, Andrew Carnegie and the Rise of Big Business (Boston: Little, Brown, 1975), pp. 149-50.

${ }^{40}$ The type of group compensation varied with the type of production. For example, producers like the Baldwin Locomotive Works that produced custom-designed products tended to rely on inside contracting schemes.
} 
type of compensation system emerged in mass-production enterprises where machines controlled the pace of work. At Ford, for example, assembly lines made it easy to detect when a worker was not able to maintain the pace. By paying wages that were high enough so that workers wanted to keep their jobs, and dismissing workers who could not make the grade, Ford was able to secure a high level of effort from its workforce. ${ }^{41}$

The kinds of cultural formations that had earlier reinforced networks based on long-term relationships could also be used to make hierarchies work. At the most obvious level, firms might amass workforces whose ethnic or gender heterogeneity operated as a barrier to labor organization. $^{42}$ Such divisions, however, could also be deployed to inculcate a sense of loyalty to the organization or to encourage employees to work hard. Southern textile mills' refusal to hire African-Americans aimed to give white workers a sense that they were privileged to work in unhealthy conditions at low wages. ${ }^{43}$ For similar reasons, the Ford Motor Company hired very few women during the early twentieth century. Ford deliberately coded assembly-line work as masculine, denigrating the manhood of those that could not keep up the pace while at the same

Firms that produced consumer goods like automobiles experimented with group piece rates. See John K. Brown, The Baldwin Locomotive Works, 1831-1915: A Study in American Industrial Practice (Baltimore: Johns Hopkins University Press, 1995), pp. 115-19; Daniel Nelson, Managers and Workers: Origins of the New Factory System in the United States, 1880-1920 (Madison: University of Wisconsin Press, 1975), pp. 34-78; Ernest J. Englander, "The Inside Contract System of Production and Organization: A Neglected Aspect of the History of the Firm," Labor History, 28 (Fall 1987), pp. 429-46; Nelson, "Industrial Engineering and the Industrial Enterprise, 1890-1940," in Lamoreaux and Raff, eds., Coordination and Information, pp. 35-50; Daniel M. G. Raff, "The Puzzling Profusion of Compensation Systems in the Interwar Automobile Industry," in Lamoreaux and Raff, eds., Coordination and Information, pp. 13-29.

${ }^{41}$ On Ford, see Raff, "Wage Determination Theory and the Five-Dollar Day at Ford," Journal of Economic History, 48 (June 1988), pp. 387-99. For a more general discussion of the use of "technical control," see Richard Edwards, Contested Terrain: The Transformation of the Workplace in the Twentieth Century (New York: Basic Books, 1979), pp. 111-29.

${ }^{42}$ See, for an example, David Brody, Steelworkers in America: The Nonunion Era (Cambridge: Harvard University Press, 1960).

${ }^{43}$ David L. Carlton, Mill and Town in South Carolina, 1880-1920 (Baton Rouge: Louisiana State University Press, 1982). 
time giving those who could a wage that, as one of his managers put it, would help them "to be better men."44

By replicating in their organizations the ethnic, gender, and class structure of society, firms were able to make their hierarchies seem more natural—as if those on top were destined to be there. But businesses could get more out of their work forces if they could manage nonetheless to provide all of their employees with opportunities for advancement. The solution many firms adopted was separate job ladders that gave workers evidence that hard work and loyalty would be rewarded, even if there were severe limits on the positions to which they could aspire. Insurance companies, for example, developed what were effectively separate promotion tracks for men and women, each of which made use of appropriate gender stereotypes to elicit high levels of effort. ${ }^{45}$ Other firms had separate tracks for blue-collar and white-collar workers. For these various job ladders to have the desired effect, however, workers had to have confidence that promotions would be made on the basis of merit, not favoritism. As Walter Licht has shown for the case of railroads, foremen's tendency to award plum jobs to, or otherwise favor, cronies (that is, to build their own networks of long-term relationships and exploit them for personal advantage) was a major source of labor unrest during the late nineteenth century. When railroads curbed the power of the foremen and put in place a more bureaucratic system of promotion, this source of grievance died down. ${ }^{46}$

\footnotetext{
${ }^{44}$ Wayne A. Lewchuk, "Men and Monotony: Fraternalism as a Managerial Strategy at the Ford Motor Company," Journal of Economic History, 53 (Dec. 1993), pp. 824-56.

${ }^{45}$ See Angell Kwolek-Folland, Engendering Business: Men and Women in the Corporate Office, 18701930 (Baltimore: Johns Hopkins Press, 1994).

${ }^{46}$ Licht, Working for the Railroad: The Organization of Work in the Nineteenth Century (Princeton: Princeton University Press, 1983). See also Edwards, Contested Terrain, pp. 130-162.
} 


\section{Industrial Districts and Chandlerian Firms}

The large wholesalers and retailers that emerged during the second half of the nineteenth century solved many of the information problems associated with long-distance commerce, but they also created new problems, stimulating manufacturers to attempt to bypass their services and deal directly with customers. One problem was the discrepancy in size and power between wholesalers and the many small producers who depended upon them for access to national markets. This discrepancy potentially subjected the latter to exploitation, and, not surprisingly, manufacturers complained of a litany of abuses, ranging from abrupt cancellation of orders, returns of goods on suspect claims that their quality was substandard, and theft of intellectual property. Manufacturers attempted to protect themselves by using market competition (in the form of direct sales) to gain sufficient bargaining power to induce wholesalers to behave. The emergence of large retailers, such as department stores and mail-order firms, facilitated their efforts, because it was in the interests of these new kinds of businesses to deal directly with suppliers. $^{47}$

Attempts by small manufacturers to discipline wholesalers were most likely to be successful, however, where producers of similar goods were concentrated near each other in "industrial districts." Whatever initially caused firms to locate in close proximity (access to markets or the availability of low-cost raw materials or other inputs), such clusters often persisted over time because they attracted businesses that supplied complementary products or services - for example, machinery firms that built or maintained equipment specific to the industry — and because the networks that manufacturers formed among themselves and with 
related businesses became an important source of competitive advance. Firms located in such districts tended to be smaller and more specialized than those in more isolated locations. In 1870, for example, Philadelphia's textile sector included over 600 firms, each of which tended to focus on a single step (weaving or spinning or dyeing) in the process of producing final goods, contracting with other firms in order to fill buyers' orders. This ability to join forces with a wide variety of other highly specialized producers enabled firms in such districts to customize their products to meet the needs of specific buyers and also to respond flexibly to changes in style. Moreover, because participation in such multi-firm deals was vital to success, producers had an incentive to deal fairly with each other. ${ }^{48}$

Much like tradesmen in the early nineteenth century, business people in these industrial communities interacted socially as well economically, and the resulting multidimensional relationships facilitated cooperation in other endeavors besides production. Thus manufacturers in industrial districts were able to join together to develop new ways of marketing their goods that helped them discipline wholesalers and sell directly to retailers. In Philadelphia, for example, textile manufacturers collectively built the "Bourse," a nine-story building which showcased the wares of hundreds of local firms in a central location convenient for buyers from large retailers to visit. Similarly, furniture producers in Grand Rapids, Michigan, exploited market forces by organizing huge biannual expositions to sell their wares to the trade. ${ }^{49}$

\footnotetext{
${ }^{47}$ See Philip Scranton, Endless Novelty: Specialty Production and American Industrialization, 1865-1925 (Princeton: Princeton University Press, 1997).

${ }^{48}$ See Scranton, Endless Novelty; Scranton, Proprietary Capitalism: The Textile Manufacture at Philadelphia, 1800-1885 (New York: Cambridge University Press, 1983); and Scranton, Figured Tapestry: Production, Markets, and Power in Philadelphia Textiles, 1885-1941 (New York: Cambridge University Press, 1989). For a more theoretical treatment, see Michael J. Enright, "Organization and Coordination in Geographically Concentrated Industries," in Lamoreaux and Raff, Coordination and Information, pp. 103-42.

${ }^{49}$ See Scranton, Endless Novelty, for these and other examples. See also Blaszczyk, Imagining Consumers, pp. 24-6.
} 
The use of wholesalers to reach national markets could pose problems for larger firms as well. The Singer Sewing Machine Company found, for instance, that consumers were reluctant to buy relatively expensive items like sewing machines unless they had instruction in how to use them effectively and also assurance that broken devices would be speedily and inexpensively repaired. Wholesalers proved to be unwilling to provide these costly but necessary teaching and repair services. In other words, Singer faced what Williamson has called the "externality principal" - that is, the likelihood that distributors would not make the investments required to market a product properly if the poor performance of one or more of their number could affect the reputation of the product (and hence the profitability of these investments). As Williamson's analysis would predict, Singer had to integrate vertically into distribution and take on these tasks itself if it was to build demand for its product. Beginning in the late $1850 \mathrm{~s}$, the company built a national system of sales offices, each staffed at minimum by a manager, a female demonstrator, a mechanic, and a salesman. ${ }^{50}$ These investments in distribution paid off in a growing stream of orders for sewing machines, forcing Singer to streamline its manufacturing process in order to deliver the machines in a timely fashion. In much the same way as Eli Terry had earlier innovated in the production of clocks in order to fulfill his contract, Singer redesigned both its product and its production process along American system lines, using special-purpose machine tools to turn out standardized parts that could be assembled with predominantly unskilled labor. ${ }^{51}$

Chandler's great contribution was to generalize from cases such as Singer's and argue that, in certain kinds of mass-production industries, wholesalers were not adequate to the task of national distribution and so firms had to integrate forwards into sales in order benefit from

\footnotetext{
${ }^{50}$ Chandler, The Visible Hand, pp. 302-305.

${ }^{51}$ David A. Hounshell, From the American System to Mass Production, 1800-1932: The Development of Manufacturing Technology in the United States (Baltimore: Johns Hopkins University Press, 1984), pp. 67-123.
} 
economies of scale. These industries included not only producers of complex machinery (sewing machines, harvesters and other farm equipment, and later automobiles), but also manufacturers of goods for which it was necessary to build demand, such as cigarettes (a new product in the late nineteenth century), or goods which required special handling, such as dressed beef and other perishable foods. ${ }^{52}$ Furthermore, Chandler argued, in order to avoid bottlenecks in supply (or holdup by suppliers), firms in such industries often had to integrate backwards as well as forwards. Problems with suppliers were especially likely to occur, as Williamson has pointed out, where investments had to be made in assets that were highly specific to the transaction. For example, meatpackers such as Gustavus Swift needed a predictable supply of refrigerator cars to ship dressed beef from their slaughterhouses in Chicago quickly around the country. Because meat would spoil if the specialized carriers were not available precisely when they were needed, it made sense for the meatpackers to integrate backwards and acquire their own fleets of cars. For similar reasons they also built their own networks of icehouses. ${ }^{53}$

As already noted, one advantage of industrial districts was the flexibility with which producers could respond to customers' needs and changing tastes. The integration of mass distribution with mass production in large Chandlerian firms enabled producers to lower dramatically the cost of the goods they manufactured, but the tradeoff was a significant loss of flexibility. An extreme but nonetheless instructive example is the Ford Motor Company. Henry Ford had recognized that there was potentially a huge demand for a low-priced, good-quality,

${ }^{52}$ The Visible Hand, Ch. 9. Although Chandler generalizes from the cigarette case and argues that the development of new mass production techniques led firms to integrate vertically into mass distribution in order to keep their plants running at full capacity, some of his cases (for example, sewing machines and meat packing) suggest that innovations in mass distribution came first.

${ }^{53}$ See Daniel M. G. Raff and Peter Temin, "Business History and Recent Economic Theory: Imperfect Information, Incentives, and the Internal Organization of Firms," in Inside the Business Enterprise, ed. Temin, pp. 23-5. For the history of organizational change in the meatpacking industry, see Mary Yeager, Competition and Regulation: The Development of Oligopoly in the Meat Packing Industry (Greenwich, CT: JAI Press, 1981). 
rugged, adequately powered car. He and a team of mechanics and engineers designed an automobile with simple components that could be cheaply machined and then developed a production system to manufacture this car on a mass scale by combining, on one hand, the American-system technique of using dedicated machine tools to produce highly uniform components with, on the other, the moving assembly lines that had already enabled firms in industries like meatpacking to profit from an extensive division of labor. At that time, most automobile firms bought parts from independent suppliers, but from early on Ford pursued a strategy of vertical integration in order to reduce costs and insure a ready supply of parts that precisely fit his specifications. When he moved from his Highland Park factory to the colossal River Rouge complex in Detroit, he pushed this strategy even further, producing not only parts but also most of the materials that went into them. He also invested in building a distribution system capable of selling and servicing the cars that "the Rouge" could turn out in such large quantities. By single-mindedly pursuing this strategy of mass production and vertical integration, Ford successfully lowered the cost of automobiles to a point where their purchase price was within range of the majority of American consumers. ${ }^{54}$

The Model T, produced starting in 1909, was ostensibly a "platform" car that enabled Ford to put several different body types on top of a generic chassis and power train. Nonetheless, the range of choices that the company offered consumers was extremely limited. Whether or not Ford actually spoke the famous words that customers "can have any color they want so long as it's black" matters little, for the quote accurately captured the company's philosophy. The whole thrust of Ford's system was to achieve lower costs through relentless

\footnotetext{
${ }^{54}$ Hounshell, From the American System to Mass Production, pp. 217-301; and "Why Corporations Don't Learn Continuously: Waves of Innovation and Desperation at Ford Motor Company, 1903-1996," unpublished paper.
} 
standardization. Indeed, not until the firm's market share had dropped precipitously in the late 1920s did Ford even offer consumers a choice of colors. ${ }^{55}$

Ford, of course, was an extreme case. In the 1920s, General Motors (GM) began to develop a similar platform system to give consumers considerably more choice, but here too the company's drive to keep costs low by achieving long production runs severely constrained its ability to respond to the desires of different consumers and even to changes in taste over time. ${ }^{56}$ Forecasting the demand for various models and colors was a serious problem, and GM assiduously tracked dealer sales and also experimented with new techniques of market research. ${ }^{57}$ Inevitably, however, the need to make production decisions far in advance of actual sales meant that firms like GM increasingly resorted to advertising to shape buyers' tastes—-that is, to make into objects of desire the highly standardized products that they were turning out in such quantity.

The large, vertically integrated firm arose initially in a relatively small number of massproduction industries - industries where firms were compelled by problems such as the externality principle to bypass wholesalers in order to market their output effectively. From the perspective of late nineteenth century, these kinds of enterprises were something of a special case and consequently did not attract much scholarly attention. Indeed, writing in the late 1880s the great economist Alfred Marshall scarcely noticed them. Although he recognized that large firms were emerging in certain sectors of the economy, he attributed their growth to the substitution of machinery for skilled labor and emphasized the continued importance of the

\footnotetext{
${ }^{55}$ Hounshell, "Why Corporations Don't Learn Continuously." See also Richard S. Tedlow, New and Improved: The Story of Mass Marketing in America (New York: Basic Books, 1990), pp. 112-81.

${ }^{56}$ On the development see Daniel M.G. Raff, "Making Cars and Making Money in the Interwar Automobile Industry: Economies of Scale, Economies of Scope, and the Manufacturing that Stood Behind the Marketing," Business History Review, 65 (Winter 1991), pp. 721-53.

57 Sally Clarke, "Consumers, Information, and Marketing Efficiency at GM, 1921-1940," Business and
} 
market in coordinating their inputs and outputs. Marshall denied that large firms were invariably more efficient than small, arguing that there were both advantages and disadvantages to the extended division of labor and reliance on professional managers that greater size entailed. Moreover, he devoted an entire chapter to the economic benefits (in the form of external or agglomeration economies) that followed from the clustering of small firms in industrial districts. $^{58}$

One hundred years later, however, the focus of scholarly attention had dramatically shifted, and firms in such specialized clusters were generally relegated to the "periphery" of the economy. Instead business historians concentrated their attention almost exclusively on the giant firms that dominated the economy's “center," accepting Chandler's view that the large, vertically integrated, managerially directed corporation was the archetypal modern industrial enterprise. ${ }^{59}$ What had changed in the interim was a series of merger waves that not only altered the size distribution of firms in the economy in ways that gave large-scale businesses considerably more prominence, but were taken by Chandler and his followers as confirmation of the superiority of the visible hand of management as a mechanism of economic coordination.

The earliest waves of mergers, the most important of which was the Great Merger Movement of 1895-1904, were dominated by horizontal combinations whose primary motive was to reduce price competition by increasing market power. ${ }^{60}$ But later waves consisted for the

Economic History, 25 (Fall 1996), pp. 186-95.

${ }_{58}$ Alfred Marshall, Principles of Economics (London: Macmillan, 1890), Book IV, Chs. 8-12. Of course, the early examples of vertically integrated firms were primarily American, which may explain why Marshall, a British academic, overlooked them.

${ }^{59}$ See Chandler's summary of his argument in Scale and Scope, pp. 3-46. The language of center and periphery is from Robert T. Averitt, The Dual Economy: The Dynamics of American Industry Structure (New York: W. W. Norton, 1968). For early attempts to redirect attention back toward industrial districts, see Scranton, Proprietary Capitalism; and Michael J. Piore and Charles F. Sabel, The Second Industrial Divide: Possibilities for Prosperity (New York: Basic Books, 1984).

${ }^{60}$ Chandler argued that the actual reason for these mergers was inconsequential but that, in order to succeed, the consolidations has to integrate vertically and develop a managerial apparatus capable of smoothly 
most part of acquisitions for the purpose of diversification According to Chandler, once firms built managerial hierarchies capable of coordinating multi-unit, vertically linked activities efficiently, they could exploit the economies of scope that these capacities made possible by taking on additional functions. First, however, an organizational innovation was necessary because the highly centralized organizations that large firms initially created tended to suffer from information overload when they expanded into new kinds of business activity. Chandler developed this point by recounting the experience of Du Pont during the period following the First World War. ${ }^{61}$

Du Pont, a gunpowder producer, had flourished during the war, but its officers expected the firm to suffer from severe excess capacity after the armistice. In order to avoid this eventuality, they decided to diversify into new markets, such as paint, that would exploit the firm's expertise in chemicals but also promised substantial potential for growth during peacetime. It quickly became apparent, however, that the firm's centralized managerial hierarchy could not effectively coordinate its newly diversified operations. After some halting efforts to address the problems by incremental means, the company developed and implemented a multidivisional form of organization. What the company did in effect was to form each distinct product line into a separate business, albeit one wholly owned by Du Pont. The Du Pont board determined the amount of capital to be allocated to each division, as well as the identity and tenure of the divisional heads. Like the chief executive of a company, the head of each division

coordinating the flow of inputs and outputs (see The Visible Hand, pp. 334-44). As noted above, he did not even entertain the possibility that the consolidations that integrated vertically may have succeeded, not because they were more efficient, but because they were able to erect barriers to new competition. For evidence on this point, see Lamoreaux, The Great Merger Movement, Chs. 5-6. For a theoretical rationale for this possibility, see Oliver Hart and Jean Tirole, "Vertical Integration and Market Foreclosure," Brookings Papers on Economic Activity. Microeconomics, 1990 (1990), pp. 205-76.

${ }^{61}$ The following account is from Chandler, Strategy and Structure: Chapters in the History of Industrial Enterprise (Cambridge: MIT Press, 1962), pp. 52-113. 
controlled all the functions required to support its operations, from product development and procurement on through marketing and sales, and was accountable to the owners for its profitand-loss performance. Although this change inevitably involved some loss of scale economies (functions like procurement and marketing, for example, were no longer consolidated in the central office), it gave divisional executives the wherewithal and the incentives to respond to changing conditions and opportunities in their particular business areas, at the same time freeing top managers in the central office to focus on resource allocation and long-run strategic concerns. By forcing divisional managers to compete for capital, it introduced elements of the market into the businesses' hierarchical organizations.

Although a small number of firms adopted similar managerial structures around the same time, it was not until the second half of the century that this organizational innovation came into widespread use. As the economy recovered from the twin disruptions of the Great Depression and the Second World War, the first impulse of many of the nation's largest enterprises was to follow the trail that Du Pont had blazed after World War I to protect its long-run profitability: diversify into new areas of business and adopt the decentralized multidivisional (M-form) organizational structure to manage them. Like Du Pont, these firms initially diversified into businesses that were closely related to their main production lines. In that way they could deploy more fully capabilities that they had already developed and exploit potential economies of scope. An important ancillary aim of firms that pursued this strategy was to smooth profits over the business cycle by producing goods that had complementary time patterns of demand. ${ }^{62}$

Firms could move into new product lines by building their own plants from scratch, but it was often more efficient to acquire a producer that had already developed a market niche in the

\footnotetext{
${ }^{62}$ Chandler, Strategy and Structure, pp. 324-96.
} 
area. Once firms began to use their surplus capital for the purposes of acquisition, however, it was hard to stop. If an important goal of diversification was to enable managers to stabilize earnings by producing goods for which demand was uncorrelated, then it was tempting for them to conclude that they could better accomplish this end by amassing a broad portfolio of companies in much the same way as investors might choose a portfolio of securities. Firms began to acquire companies in industries completely unrelated to their core businesses, and the result was a merger mania that grew to enormous proportions during the 1960 s and early ' $70 \mathrm{~s}$. During the high tide of the conglomerate movement, some companies acquired more firms than there were days in a year. ${ }^{63}$

Thus, by the time Chandler sat down to write The Visible Hand during the mid 1970s, the large vertically integrated, horizontally diversified, managerially coordinated enterprise had come to account for a broad swath of the nation's economic activity. Not only had large firms apparently translated success in their core businesses into other economic activities, but they had managed to maintain their positions of dominance for unprecedentedly long periods of time. Richard Edwards, also writing during the mid-1970s, found that there had been remarkably little change in the ranks of the nation's largest corporations between 1919 and 1969: virtually all the firms that dominated their industries in 1919 were still at the top of the list in 1969. Moreover, these same American corporations (or foreign companies that appeared to be structured along similar lines) had triumphed by the $1970 \mathrm{~s}$ in the international arena as well. ${ }^{64}$ Given this record,

\footnotetext{
${ }^{63}$ According to Bruce Kogut and David Parkinson ("Adoption of the Multidivisional Structure: Analyzing History from the Start," Industrial and Corporate Change 7 (1998), pp. 249-73), use of the M-form was relatively limited in 1950, higher in 1960, and much higher after that. For a case study of one of the most active conglomerates of this period, see George P. Baker, "Beatrice: A Study in the Creation and Destruction of Value," Journal of Finance, 47 (July 1992), pp. 1081-119.

${ }^{64}$ Richard C. Edwards, "Stages in Corporate Stability and the Risks of Corporate Failure," Journal of Economic History, 35 (June 1975), pp. 428-57; and Thomas K. McGraw, Prophets of Regulation: Charles Francis Adams, Louis D. Brandeis, James M. Landis, Alfred E. Kahn (Cambridge: Harvard University Press, 1984), pp. 74-
} 
it is perhaps not surprising that Chandler's view that the vertically integrated, managerially coordinated firm was the modern industrial enterprise swept the profession.

\section{Market Revolution II}

Things would soon change, however. When Leslie Hannah revisited the subject during the late 1990s, he found that the relative position of once dominant American firms had deteriorated dramatically. Of the 54 U.S. firms that ranked among the top 100 in the world in 1912, only 17 retained that status in 1995. Moreover, despite large numbers of mergers in the intervening years, only 26 of the 54 actually had capitalizations in 1995 that were greater (adjusting for price changes) than they had been in 1912. In other words over half of the firms had lost ground in absolute as well as in relative terms during the intervening years. ${ }^{65}$

At the root of this deteriorating performance were changes in the economic environment that necessarily affected the adaptability of the hierarchical coordination mechanisms employed by large vertically integrated, horizontally diversified firms. The sudden onslaught of international competition during the 1970s highlighted the seriousness of problem, but the underlying sources of the firms' difficulties were largely domestic. Rising per capita income had shifted consumers' preferences toward higher quality, more individuated goods, but the firms' hierarchical organizations proved rigid and unresponsive. At the same time, the circumstances that had encouraged vertical integration in the first place had to a large extent disappeared. As transportation and communications costs continued to fall, markets became thicker and problems such as asset specificity and the externality principle became less pressing. Firms found that it

7.

${ }^{65}$ Leslie Hannah, "Marshall's 'Trees' and the Global "Forest': Were 'Giant Redwoods' Different?" in Lamoreaux, Raff, and Temin, eds., Learning by Doing, pp. 253-86. 
was now in many cases more efficient to buy inputs than to make them. They also found that, by shifting from in-house production to markets and long-term relationships, they were able to respond more nimbly to rapidly changing and increasingly varied consumer tastes.

The disadvantages of the hierarchical coordination techniques employed by Chandlerian firms appeared earliest and most obviously in the case of conglomerates. These mergers had been rationalized on the grounds that executives in the central office would be able to make their subsidiary companies more profitable than they had been on their own and, therefore, that investors were better off buying shares in a conglomerate than in an assortment of free-standing companies. In the beginning, there may have been some truth to this notion. Systematic education in business administration was not widespread in the United States, even during the 1950s, and many of the early conglomerates were able to improve performance by buying up less than professionally managed firms and immediately putting in place up-to-date accounting and reporting systems and a managerial staff instructed to achieve specific measurable outcomes. ${ }^{66}$

These kinds of gains were relatively quickly exhausted, however, and the effectiveness of this kind of managerial structure was soon called into question. Top executives in the central office had only summary knowledge of the businesses that they acquired and, as a result, found it difficult to review critically the opportunities, decisions, and outcomes of their many divisions in detail. Over time they increasingly restricted themselves to setting performance targets in terms of easily interpreted financial variables like revenue, profit, and return on invested capital, allocating capital among their many divisions not on the basis of their superior understanding of the choices at issue but rather strictly by the numbers.

\footnotetext{
${ }^{66}$ Baker, "Beatrice," pp. 1091-3.
} 
In effect, what top executives were attempting to do was to evaluate divisional managers' performance by using rate-of-return accounting to mimic market competition. Not only did this kind of direction add less and less value over time, it could be downright harmful. In the first place, the organizational routine of target-setting and frequent evaluation tended to focus executives' attention on specific short-term targets rather than the sort of longer-term strategic planning needed to ensure the firm's continued success. Second, as the underlying businesses grew more complex - that is, as the divisions' own product offerings grew more diversified in response to emerging consumer wants - accounting systems that were well suited to monolines became grossly inappropriate, giving useless and sometimes positively misleading information about the structure of costs and ultimately about the sources of profits. In other words, the metrics that the firm used internally to mimic market competition were increasingly poor indicators of how the market was in fact evaluating the division's performance. Finally, management by the numbers created incentive structures that rewarded subsidiaries for achieving long production runs that spread fixed costs over a large output, compounding the measurement problem by encouraging managers to sacrifice quality in the interests of quantity production. ${ }^{67}$ Perhaps unsurprisingly, by the 1980s the capital markets had begun to discount the value of central-office control as a coordination mechanism and impose a penalty (in the form of relatively lower share prices) on diversified firms. ${ }^{68}$ Also not surprisingly, shareholders began to take action to break up these concerns. During the 1980s these break-ups largely took the form

\footnotetext{
${ }^{67}$ See Robert H. Hayes and William J. Abernathy, "Managing Our Way to Economic Decline," Harvard Business Review, 58 (July-Aug. 1980), pp. 67-77; Andrei Shleifer and Robert W. Vishny, "The Takeover Wave of the 1980s," Science, 249 (17 Aug. 1990); and H. Thomas Johnson, "Managing by Remote Control: Recent Management Accounting Practice in Historical Perspective," in Temin, ed., Inside the Business Enterprise, pp. 4166.

${ }^{68}$ See Larry H. P. Lang and Rene M. Stulz, "Tobin's Q, Corporate Diversification, and Firm Performance," Journal of Political Economy, 102 (Dec. 1994), 1248-80; and Philip G. Berger and Eli Ofek, “Diversification's Effect on Firm Value," Journal of Financial Economics, 37 (Jan. 1995), pp. 39-65.
} 
of hostile takeovers and leveraged buyouts (LBOs) because entrenched managerial hierarchies seemed unable or unwilling to reform themselves in response to changed economic conditions. By the next decade, however, the use of hostile methods had declined as large firms strove to internalize the lessons of the preceding decade. By tying executive compensation to the performance of the corporation's stock and giving shareholders a greater role in monitoring the firm's activities, they attempted to decrease the managerial autonomy that characterized the Chandlerian firm in favor of a mixture of hierarchical with more market-based methods of coordination. By relying on financial marked signals to determine the direction and even the identity of management, business leaders today have brought markets into the heart of the Chandlerian firm. ${ }^{69}$

Regardless of the method of reform, the end result of the restructuring of the 1980s and 1990s was a striking retreat from conglomeration. According to one calculation, by 1989 firms had divested as many as 60 percent of the acquisitions they had made outside their core businesses between 1970 and 1982. The deals that led to these divestments generally took one of two major forms. In the first, one large firm bought another which had substantial investments in its core business, increasing its market share in that activity and spinning off unrelated subdivisions at the same time. In the second, the so-called "bust-up," the various parts of a conglomerate were sold off separately, usually to firms specializing in the same line of business as the division. In either case, the end result was to increase the extent to which large firms focused their energies and resources on their core businesses. Although most of the nation's

${ }^{69}$ See Bengt Holmstrom and Steven N. Kaplan, "Corporate Governance and Merger Activity in the United States: Making Sense of the 1980s and 1990s," Journal of Economic Perspectives, 15 (Spring 2001), pp. 121-44; Michael C. Jensen, "Takeovers: Their Causes and Consequences," Journal of Economic Perspectives, 2 (Winter 1988), pp. 21-48; Jensen, "The Modern Industrial Revolution, Exit, and the Failure of Internal Control Systems," Journal of Finance, 48 (July 1993), pp. 831-80; and George P. Baker and George David Smith, The New Financial Capitalists: Kohlberg Kravis Roberts and the Creation of Corporate Value (New York: Cambridge University 
largest enterprises continued by historical standards to be highly diversified, these deals marked a significant shift back in the direction of specialization. ${ }^{70}$

There was also during this period a significant retreat from vertical integration. Although reliable quantitative measures of the extent of the trend are not available, the anecdotal evidence is suggestive. The steel industry is a good example. The large firms that dominated this industry since early in the century had managed to forestall entry by integrating backward into ore reserves and other raw-material resources, effectively preventing potential domestic entrants from gaining access to the inputs they needed to compete effectively. Protected as well from foreign sources by high transportation costs, U.S. firms had little incentive to stay abreast of technological developments around the world. By the 1970s, however, the development of new kinds of bulk-capacity ships had caused transportation costs to fall, allowing low-cost sources of iron ore to be exploited in distant parts of the world. Imports surged, and in the face of competition from new more technologically sophisticated rivals, U.S. firms collapsed. When the domestic industry began to recover during the next decade, it was organized very differently. The giant integrated firms of the previous era were in retreat and in their place had emerged a relatively large number of smaller, more specialized firms, each of which tended to focus on a particular stage of the production process and on one or two types of outputs. ${ }^{71}$

In the automobile industry the limitations of the large, vertically integrated firm had become increasingly apparent by the 1970 s as well. Detroit had experienced something of a

\footnotetext{
Press, 1998).

${ }^{70}$ Sanjai Bhagat, Andrei Schleifer, and Robert W. Vishny, "Hostile Takeovers in the 1980s: The Return to Corporate Specialization," in Brookings Papers on Economic Activity: Microeconomics, 1990 (1990), pp. 1-72. On the extent to which firms continued to be diversified, see Cynthia Montgomery, "Corporate Diversification," Journal of Economic Perspectives, 8 (Summer 1994), p. 164. Montgomery calculated that, in 1992, only about 12 percent of the 500 largest U.S. companies operated in a single (four-digit) SIC industry, whereas nearly 70 percent operated in more than five and more than 40 percent in excess of 10 .

${ }^{71}$ See Christopher G. L. Hall, Steel Phoenix: The Fall and Rise of the U.S. Steel Industry (New York: St.
} 
golden age during the quarter century after World War II, but organizational routines at the Big Three auto makers had become increasingly dysfunctional. Seduced by the vastness of the seemingly secure domestic American market, top executives increasingly evaluated divisional performance strictly by the numbers, and divisional managers responded predictably by focusing on short-term returns. Relatively superficial product differentiation and extended production runs became the main paths to profits, and, in the pressure to exploit economies of scale, quality suffered. The main incentive to invest in improving quality was the cost of honoring warranties to customers. This cost proved to be not much of an incentive, and manufacturers simply shifted the problem to their dealers. Blaming the company's large numbers of defective automobiles on the low quality of its workforce, Ford's president Lee Iacocca asserted that there was nothing manufacturers could do to solve the problem: "We can't change a man," he claimed, "so what we're going to do at Ford is create a dealer organization that will fix up the cars and guarantee that they'll function right. We'll give you a dealer who will repair what we produce."72 Rather than work to improve quality, the company was going to depend on its dealers to pick up the slack!

Toyota became a force in the American automobile market in the aftermath of the oil crisis of the early 1970s. As the price of gasoline climbed, consumers found small, fuel-efficient imported cars increasingly more attractive than the powerful, heavy American models. As the market share of U.S. firms in their home market dropped, students of the industry observed that Japanese producers, and Toyota in particular, were not only selling what Americans wanted at the time but were actually better than the U.S. companies at manufacturing. Japanese firms were

\footnotetext{
Martin's Press, 1997).

72 David Halberstam, The Reckoning (New York: Avon Books, 1986), p. 467. See also Hounshell, "Why Corporations Don't Learn Continuously".
} 
in a better position to compete in the changed U.S. economic environment because they were able to provide consumers with higher quality cars and also to respond flexibly to the more individuated structure of demand. By 1989 they accounted for 27 percent (by number) of the cars sold in the U.S. market but fully 41 percent of the different models of cars available. The impact of the wider choice they introduced to the market is indicated by the sharp drop in the share captured by the six largest-selling automobiles from 73 percent in 1955 to 24 percent by 1989. Over the same period the number of different cars on the market increased from 30 to $142 .^{73}$

Originally a textile firm with a history of innovation, Toyota had moved into automobile manufacturing during the difficult interwar years. The Japanese automobile market was not large to begin with, and the presence of local assembly plants of the giant American firms Ford and General Motors had obliged the company, government assistance notwithstanding, to address differentiated demand in a flexible way from the very start. ${ }^{74}$ It also led the firm to invest in its suppliers and in its relations with them. ${ }^{75}$ These investments were partly financial, but they had an important operational side that included support for a significant devolution of responsibilities for component design to suppliers, as well as for the training of suppliers'

${ }^{73}$ The data are from James P.Womack, Daniel T. Jones, and Daniel Roos, The Machine That Changed the World (New York: Rawson Associates, 1990), p. 125. The authors defined a product as a vehicle selling more than 1000 units in the U.S. market annually that shared no external panels with, and had a different wheelbase from, any other product that the company sold. Cars were assigned to countries according to the location of the company's headquarters.

${ }^{74}$ William Mass and Andrew Robertson, "From Textiles to Automobiles: Mechanical and Organizational Innovation in the Toyoda Enterprises, 1895-1933," Business and Economic History, 25 (Winter 1996), pp. 1-37; Takahiro Fujimoto The Evolution of a Manufacturing System at Toyota (New York: Oxford University Press, 2000); Stephen Spear and H. Kent Bowen, "Decoding the DNA of the Toyota Production System," Harvard Business Review, (Sept.-Oct. 1999), pp. 96-106; Michael Cusumano, The Japanese Automobile Industry: Technology and Management at Nissan and Toyota (Cambridge: Harvard University Press, 1984). For a more detailed account of the contrast to the American approach, see Charles H. Fine and Daniel M. G. Raff, "Internet-Driven Innovation and Economic Performance in the American Automobile Industry," in Robert Litan and Alice Rivlin, eds., The EBusiness Transformation: Sectoral Developments and Policy Implications (Washington, D.C.: Brookings, 2001), pp. $62-86$.

\footnotetext{
${ }^{75} \mathrm{We}$ abstract here from the details of a complex tiered system. See, for example, Toshihiro Nishiguchi,
} 
workforces, help with the organization of production, and the development of just-in-time routines for coordination and delivery of the components - all in the context of a committed and ongoing relationship in which problems were resolved via voice rather than exit. ${ }^{76}$ Toyota functioned, and conceived of itself, as the hub of a network of distinct companies. It could not, for many years, have afforded anything else; but in a dynamic world, it profited greatly from the capabilities for change and improvement that this network arrangement gave them.

As the market share of Toyota and other Japanese firms increased relative to domestic producers in the decade following the oil shock, American firms tried to figure out the source of the newcomers' advantage. Executives went on factory tours, knowledgeable consultants developed busy practices and published books for executives to study, and GM undertook a joint venture with Toyota. ${ }^{77}$ But the organizational structures of the big three American auto makers could not so easily be transformed. U.S. firms in general were much more vertically integrated than their Japanese counterparts. Moreover, such long-term relations as they had with outside suppliers tended to be more hierarchical, with U.S. firms using control of designs, short-term contracts, multiple sourcing, and other similar tactics to force their suppliers into a passive role. ${ }^{78}$ Chrysler went furthest in the Japanese direction, mainly because its financial crisis during the late 1980 s forced it to develop more egalitarian relationships with its suppliers. At the other extreme, General Motors, found change much more difficult. Despite the opportunity for

Strategic Industrial Sourcing: The Japanese Advantage (New York: Oxford University Press, 1994) for details.

${ }^{76}$ Susan Helper, "Strategy and Irreversibility in Supplier Relations: The Case of the U.S. Automobile Industry," Business History Review, 65 (Winter 1991), pp. 781-824.

${ }^{77}$ See James P, Womack, Daniel T. Jones, and Daniel Roos, The Machine that Changed the World (New York: Rawson, 1990); and Joseph L. Badaracco, "General Motors' Asian Alliances" (Harvard Business School Case No. 9-388-094). A close reading of this case suggests that Toyota got more out of the venture than General Motors did.

${ }^{78}$ Helper, "Strategy and Irreversibility in Supplier Relations"; Michael Schwartz, "Markets, Networks, and the Rise of Chrysler in Old Detroit, 1920-1940," Enterprise and Society, 1 (March 2000), pp. 63-99; Robert Crandall, "Vertical Integration in the United States Automobile Industry," unpublished Ph.D. diss., Northwestern University, 1968. 
learning provided by a joint venture with Toyota in California, and despite its success in setting up a wholly-owned subsidiary to manufacture a new product (the Saturn car) using Japanese methods, the company was unable to diffuse what it learned to other facilities. Indeed, GM's main response to its falling market share seems to have been to implement even more aggressive arms-length and price-oriented relations with suppliers. ${ }^{79}$

Although auto makers found it difficult to reorganize their supply systems along lines similar to Toyota, firms in other manufacturing industries like computers have extensively exploited the possibilities for flexible production inherent in just-in-time inventories and network relations with suppliers. The Dell Computer Company is an excellent example. Dell uses these techniques to enable it cheaply to custom-build computers for individual purchasers. Dell takes orders by phone, fax, mail, or internet, and then immediately requests components from its suppliers - components that typically are delivered and assembled into computers that same day. A reporter for Fortune followed an order called in one morning at 10:49AM and reported that a driver for Airborne Express put the finished product on a truck at 9:25 that same night. Five of the intervening hours were spent testing the computer for defects. ${ }^{80}$

Dell buys parts from a relatively small number of suppliers who are willing to make the investments necessary to keep technologically up to date and also to meet the company's rigorous just-in-time delivery needs. Through a process it calls "virtual integration," Dell signals its suppliers to provide specified types and numbers of components at various times throughout

${ }^{79}$ Badaracco, "General Motors' Asian Alliances." For a time series on return on assets, profit per unit production, and market share suggesting the progress the big three auto makers made over the decade 1988 to 1998 , see Jeffrey H. Dyer, Collaborative Advantage: Winning through Extended Enterprise Supplier Networks (New York: Oxford University Press, 2000), p. 147.

${ }^{80}$ See Stephanie Losee, "Mr. Cozzette Buys a Computer," Fortune, 129 (18 April 1994), p. 113. For some limits to the extent of customization, see Joe Abernathy, "Customize . . or Compromise?" PC World, 13 (July 1995), p. 72. The Dell firm was created - in a University of Texas dormitory room — with this sort of production model in mind. It had no burden of the past to throw off. 
the day to specific factory locations. Suppliers that do not make deliveries on time risk penalties much more drastic than those faced earlier in the century by Sears's internal departments, which only had to shoulder extra shipping costs in their budgets. Dell's suppliers risk losing these lucrative contracts entirely. But Dell helps them out by giving them direct, "real-time" access to its order books so they can plan their production and delivery schedules effectively. ${ }^{81}$

In other parts of the computer industry, networks of long-term connections among firms have become so dense and so geographically concentrated that they have taken on all of the characteristics of a Marshallian industrial district. Silicon Valley, of course, is the pre-eminent example. Firms in the Valley are generally small and highly specialized. Although they compete with each other vigorously, they also share technological information and cooperate in joint ventures in order to meet specialized consumer needs - just as firms did in the textile industry in late-ninteenth-century Philadelphia. According to Annalee Saxenian, in technologically dynamic industries like computers, large managerial enterprises are at a competitive disadvantage. She contrasted the experience during the 1980 s of the more hierarchical firms located along Boston's "Route 128" with those in the Silicon Valley and found that the latter's fluidity better enabled the local industry to weather swings in demand and also stay abreast of technological developments. ${ }^{82}$

Although most firms in the Silicon Valley region are small, a few large enterprises have emerged - the most notable being Intel and Hewlett-Packard (HP). Interestingly, these firms attempted in their internal structures to mimic the openness of the Valley in general. For

\footnotetext{
81 "You'll Never Walk Alone," Economist, 351 (26 June1999); Joan Magretta, "The Power of Virtual Integration," Harvard Business Review (Mar.-Apr. 1998).

${ }^{82}$ Annalee Saxenian, Regional Advantage: Culture and Competition in Silicon Valley and Route 128 (Cambridge: Harvard University Press, 1994). For the history of the Silicon Valley's industrial-district structure, see the essays in Chong-Moon Lee, William F. Miller, Marguerite Gong Hancock, and Henry S. Rowen, eds., The Silicon Valley Edge: A Habitat for Innovation and Entrepreneurship (Stanford: Stanford University Press, 2000).
} 
example, Hewlett-Packard tried to foster a spirit of community rather than hierarchy among its employees. There were no fancy offices or perks for top executives. All employees ate in the same cafeteria and were given the same stock options, profit-sharing arrangements, and benefits. In order to maintain flexibility HP adopted a decentralized organizational structure, in which each major product line was managed as a separate, semi-autonomous division. Unlike traditional M-form executives, divisional managers at HP had "ownership" rights to their businesses. They could formulate their own competitive and product-development strategies without waiting for orders from above, and they could reinvest the capital generated by their divisions as they saw fit. Even so, HP was not able completely to escape the disadvantages of hierarchy. By the last decade of the twentieth century, declining profits and complaints by industry analysts about growing bureaucratization had forced the firm to cut its size and refocus its energies. As part of this effort, it spun off its measurement instruments division (the original business of the firm) into a separate company called Agilent. ${ }^{83}$

Another large firm in the computer industry is Microsoft. While not integrated backward into manufacturing or forward into sales, Microsoft dominates the market for applications like word-processing, spread-sheets, and internet browsers, as well as its core business of producing operating systems. A federal appeals court found Microsoft guilty of illegally using its power in the latter market to monopolize the former, implying that it was not the logic of costs that accounted for Microsoft's imposing share of both sectors. Nonetheless, the possibility remains that the network character of the software business compels monopoly and even some degree of vertical integration. If so, then the Microsoft case underscores the diversity of ways in which

\footnotetext{
${ }^{83}$ Saxenian, Regional Advantage, pp. 50-1; Alan Deutschman, "How H-P Continues to Grow and Grow," Fortune, 129 (2 May 1994), p. 90; "Reinventing Company of Inventors," Financial Times (16 Nov. 1999), p. 35; "HP Problems 'Will Take Time to Fix," Financial Times (18 Nov. 1999), p. 19.
} 
firms successfully responded to the changing conditions of the late-twentieth-century economy. We do not at all mean to suggest that large firms do not continue to play an important role in the nation's economic life, though it should be noted that Microsoft is significantly less vertically integrated than the firms that Chandler celebrated.

Large, vertically integrated, diversified manufacturing firms were not the only hierarchical enterprises to suffer from the changes of the late twentieth century. National retailers like mail-order firms and department-store chains were affected as well. Since the late nineteenth century, such enterprises had employed professional buyers to track changing fashions and to stock inventories accordingly, but the long lead time that manufacturers required to produce the desired goods meant that orders had to be placed substantially in advance of the period in which they would be consumed, increasing the possibility that buyers would misjudge the direction of consumer tastes. Stores traditionally dealt with errors of judgment by selling unsold merchandise at clearance prices at the end of each season. Beginning around the mid1960s, however, the problem suddenly got worse as rising per capita income made Americans less tolerant of standardized commodities and more interested in purchasing goods that expressed their individual tastes. To give one example, the market share of white bed sheets dropped from about 75 percent in 1960 to about 20 percent by the mid-1970s, whereas the share of fancy patterned sheets showed precisely the opposite trend. Men similarly shifted away from white shirts, women from tailored clothing, and there was a general move toward more casual clothing in a greater variety of styles, fabrics, and colors. As tastes became more diverse and merchants strove to satisfy them, the chance that buyers would make errors in stocking merchandise increased. Department stores coped with this problem in two ways: by increasing the general markup they charged on merchandize and by putting items that did not sell on sale more 
frequently. But they made no fundamental changes to their organization or to their abilities to capture and process information and to act upon it. ${ }^{84}$

This situation offered new national chains of specialty boutiques an opportunity to take substantial chunks of business away from more traditional retailers. In apparel, the two leading examples were The Limited and The Gap. Riding the wave of bar codes, scanners, and the new information technology more broadly, these innovative retailers learned how to manage their inventories flexibly so as to reduce errors in stocking merchandise. Their checkout scanners, which read barcodes that contained detailed information on each item sold, generated immense amounts of data (style, color, and size) on precisely what was selling when in every store location. Managers analyzed the patterns — local, regional, and national — in the data, and continually adjusted orders (and sometimes prices), rerouted shipments, and revised the assortments offered by particular stores. ${ }^{85}$ Similar techniques led to the success of other “category killers" like Toys R Us, Circuit City, and Borders - thus called because of the consequences they had for the range of goods department stores profitably could stock and sell. These businesses used sophisticated analysis of local sales histories and related information to tailor and support unprecedentedly broad assortments of goods. By relying upon just-in-time, supply-chain relationships similar to those of Toyota and Dell, moreover, they were able to

\footnotetext{
${ }^{84}$ In addition to demand-side shifts favoring variety, there were also supply-side changes (for example, the spread of the shuttleless loom) that made it possible to produce patterned fabrics more cheaply. B. Peter Pashigian, "Demand Uncertainty and Sales: A Study of Fashion and Markdown Pricing," American Economic Review, 78 (Dec. 1988), pp. 936-953; and Pashigian and Brian Bowen, "Why Are Products Sold on Sale?: Explanations of Pricing Regularities," Quarterly Journal of Economics, 106 (Nov. 1991), pp. 1015-1038.

${ }^{85}$ See Raff and Temin, "Sears, Roebuck in the Twentieth Century," pp. 241-2, summarizing unpublished research by Raff and Walter Salmon, for an account of how the coordination systems differ and for estimates of the dramatically superior economic performance the new model could induce.
} 
manage all this variety far more profitably than was possible even for a narrower set of offerings under the old department-store system of ordering. ${ }^{86}$

The result of all these innovations was to provide consumers with a vastly greater selection of choices within any particular product category. The advance of communications technology pushed this development even further by ushering in the age of internet marketing, where - in a fashion reminiscent of the early years of Sears and other mail-order firms, but without the ensuing communication disadvantages — retailers consisted of little more than customer interfaces. In the book trade, Amazon.com pointed the way. When Jeffrey Bezos started the company in 1995, he located it in Seattle near a distribution center operated by Ingram, at the time the industry's largest and most efficient wholesaler. Amazon maintained very few books in its own inventory_-perhaps as little as four hundred at the beginning — but it made enormous investments in advertising and in developing for its website a search engine that could speedily locate items in a massive database of books in print that it purchased from trade sources. Amazon's website made it possible for anyone with access to the internet to order any book from this database, most at substantial discounts from prices charged in brick-and-mortar stores, and sales grew rapidly. (Profits were much slower in appearing though the company claimed its book-selling division was showing an operating profit by the fourth quarter of 1999.). ${ }^{87}$

The internet is not itself a coordination mechanism but rather a coordination infrastructure - the most recent development in a long history of infrastructural improvements that have brought down the costs of communication. Yet the speed and ease with which the

${ }^{86}$ Supply-chain management has also been a key factor in the success of a new generation of mass retailers. Wal-Mart, for example, provides direct computer feeds from its individual checkout scanners to its leading suppliers, leaving it to them to manage efficiently the shelf space they are allocated.

${ }^{87}$ Daniel M. G. Raff, "Revolution in the Book Trade" typescript case study, Wharton School, University of Pennsylvania. Note well that operating profit is not what stock analysts or investors generally regard as profit-it excludes various charges on the enterprise legitimately regarded as costs of doing business. 
internet makes search and information transfer possible suggests that its effect on the incidence of specific coordination mechanisms may be profound. As vendors accumulate information on the interests and preferences of individual consumers, it may be possible for them to present both individualized offerings (economizing on the customers' search time) and individualized pricing (economizing on the amount of the resultant surplus with which the consumer walks away) in much the same way as craftsmen in the early nineteenth understood local buyers' wants and could price accordingly. ${ }^{88}$ Amazon has pushed ahead on both frontiers. For example, it makes recommendations to customers on the basis of their past purchases, as well as on the selections of other customers who, its data bases suggest, have similar tastes. Moreover, its consumer electronics department has experimented (disastrously) with so-called "dynamic pricing"— that is, with charging higher prices to buyers who the company estimates (on the basic of the past behavior) are willing to trade off price for convenience. What Amazon did not properly appreciate, however, was that the same coordination infrastructure that made it possible to learn so much about individual consumers' preferences also enabled individual consumers to learn about Amazon's pricing practices. Just as customers in an early period might have dealt with worries about overcharging by telling each other about the prices they were charged, Amazon's customers exchanged information with each other. The mechanisms were somewhat differentinternet chat rooms versus conversations at local gathering places-but the end result was very similar. Amazon's violation of consumers' trust was publicly exposed, and the company had to apologize and make amends. ${ }^{89}$

\footnotetext{
${ }^{88}$ Eric J. Johnson, Wendy Moe, Peter S. Fader, Steven Bellman, and Jerry Lohse "On the Depth and Dynamics of Online Search Behavior," Wharton School Marketing Department Working Paper 00-019.

${ }^{89}$ Michael J. Martinez, "Amazon Error May Shut the Door on 'Dynamic Pricing,"” Associated Press State and Local Wire, 28 September 2000, Lexis-Nexis Academic Universe (http://web.lexis-nexis.com/universe/)
} 


\section{Retrospect and Prospect}

The overview of American business history that we have offered in this paper is still sketchy and incomplete. We have been largely silent about a number of issues that clearly matter - most obviously, the role that government has played in the economy during the twentieth century - and we have not provided any quantitative measures of the relative importance of different kinds of coordination mechanisms over time. Moreover, because our space is limited and the main purpose of our narrative has been to describe the great variety of techniques that were successfully in use at each point in American history, we have not been able to convey the trial and error processes by which real economic actors, with sunk investments in existing ways of doing things and only imperfect information about alternative courses of action, confronted (sometimes unsuccessfully) the ongoing coordination problems they faced.

Nonetheless, by expanding on the familiar opposition between markets and hierarchies we have been able to provide a more complex history of American business than is available in the literature. This complexity is important because the considerable heterogeneity that we have observed, both cross-sectionally and over time, provides raw material for generalizing about the relative advantages and disadvantages of different forms of business organization. More importantly, at the same time as it enables us to draw lessons from our survey of American business history, it allows us to maintain both a backward- and a forwarding-looking perspective on the nature of organizational change.

A backward-looking perspective is valuable because it allows us to study the secular patterns that underpinned changes over time in the predominant ways in which business activity has been coordinated. Our survey, for example, has revealed an intriguing juxtaposition of 
trends. On the one hand, there has been, since the early nineteenth century, a more or less steady decline in transportation and communication costs and also a more or less steady rise in per capita income. Yet despite these cumulative unidirectional, almost linear, trends, the degree of hierarchical coordination in what have conventionally been regarded as the center parts of the economy has followed a pronounced hump-shape pattern over time. That is, as transportation and communication costs fell with the spread of the railroad and telegraph in the second half of the nineteenth century (the first market revolution) firms responded by substituting hierarchical for other forms of economic coordination, integrating forward into distribution and backward into supply and developing managerial organizations to coordinate these activities (organizations which, in the next period, were used to take on additional activities). But then as transportation and especially communication costs continued to fall in the computer era (the second market revolution) firms responded by shifting away from both conglomeration and vertical integration, increasingly substituting for their managerial hierarchies coordination by long-term relationships.

The perspective of hindsight enables us to see that this puzzling combination of trends can be attributed in part to the effects of communication and transportation costs on the location and organization of economic activity. When these costs are high, economic activity tends to be local and consequently small in scale. At the other extreme, when communication is virtually free, as on the internet, and transportation is very cheap, then economic activity can be located anywhere and even tailored to individual needs. In the middle, however, when communication and transportation costs are neither prohibitive nor trivial, there are advantages to be obtained from concentrating productive activity in specific locations and in large firms. ${ }^{90}$

${ }^{90}$ See Paul Krugman, Geography and Trade (Cambridge, MIT Press, 1991). 
Trends in per capita income had a similar effect on the organization of economic activity. During the nineteenth century, most households had relatively small surpluses to spend on products not required for basic subsistence, and their ability to expand the range of goods they consumed was largely a function of cost. In a situation where the price of most manufactured items put them beyond consumers' reach, there were big rewards to be earned by lowering the cost of production. By the late twentieth century, however, rising per capita income had shifted the reward structure toward firms that were able to respond more flexibly to consumer wants. As we have seen, large vertically integrated mass-production firms were able to produce goods at low cost but the tradeoff was an increase in standardization. This was an exchange that consumers were willing to make in the late nineteenth century, but they were less willing to accept this tradeoff a hundred years later. When new firms emerged in the late twentieth century that substituted long-term relationships for vertical integration and were thus better able to accommodate preferences for greater quality and choice, consumers voted with their feet.

This explanation for the origins of the "new economy" is itself a valuable contribution to the literature. Not only does it significantly modify the Chandlerian framework, it forces us to reassess other unidirectional theories of change that have influenced historical writing. For example, members of the so-called market-revolution school have argued that the economy underwent a transition to capitalism during the late eighteenth and early nineteenth centuries, as a result of which the personal connections that hitherto had governed exchange (and kept rapaciousness under control) were disrupted by the growth of broad, impersonal markets in which there was little or nothing to restrain human greed. ${ }^{91}$ Our analysis suggests, by contrast,

\footnotetext{
${ }^{91}$ See Michael Merrill, "Cash is Good to Eat: Self-Sufficiency and Exchange in the Rural Economy of the United States," Radical History Review, 4 (1977), pp. 42-71; Christopher Clark, The Roots of Rural Capitalism: Western Massachusetts, 1780-1860 (Ithaca: Cornell University Press, 1990); James Henretta, The Origins of American Capitalism: Collected Essays (Boston: Northeastern University Press, 1991); and Charles Sellers, The
} 
that long-term connections (and the informal restraints on self-interested behavior with which they are associated) have continued to play an important role in exchange-indeed that they can be considered a third major type of coordination mechanism whose significance has waxed as well as waned over time. In a similar vein, our analysis allows us to contextualize the assertion that, by the early twentieth century, vertically-integrated corporations were able to exert a Gramscian-style hegemony over Americans' consumption choices. ${ }^{92}$ By emphasizing the links between different kinds of coordination mechanisms and particular marketing arrangements, we have provided an alternative to the increasingly sterile debate over this claim - that is, we have provided historians with a means of understanding the shifts that have occurred over time (and are still occurring) in the relative power of producers and consumers.

Although our analysis also helps us understand the forces at work in the economy (and therefore presumably is of some use in predicting the direction of economic change), we believe that it would be a serious mistake to consider the organizations that appear to be characteristic of the present era as a new endpoint toward which history has been evolving. ${ }^{93}$ Although the longterm relationships that are at the heart of the new economy certainly offer advantages of flexibility, in order for them to hold up over time they must be profitable for all parties involved. Such mutual profitability, however, can be difficult to sustain in a dynamic environment where fluctuations or downward trends in demand can result in excess capacity. In a market situation, manufacturers can simply reduce orders from suppliers to bring their production in line with demand. In case of long-run relationships, however, manufacturers must try to reduce the

Market Revolution: Jacksonian America, 1815-1846 (New York: Oxford University Press, 1991).

${ }^{92}$ See Stuart Ewen, Captains of Consciousness: Advertising and the Social Roots of the Consumer Culture (New York: McCraw-Hill, 1976); Richard Wightman Fox and T. J. Jackson Lears, eds., The Culture of Consumption: Critical Essays in American History, 1880-1980 (New York: Pantheon, 1983); William Leach, Land of Desire: Merchants, Power, and the Rise of a New American Culture (New York: Vintage, 1993).

${ }^{93}$ For an example of this kind of analysis, see Langlois, "The Vanishing Hand." 
burden on their contractees in order to maintain their supply network. ${ }^{94}$ If they cannot steer new work to their suppliers or help them find other customers, they must shoulder some or all of the costs of the downturn themselves by accumulating inventory. In more severe downturns, however, they may be forced to engage in triage, severing their relationship with some of their suppliers in order to maintain a smaller base of viable partner firms. In the worst depressions, manufacturers may not be able to do even that.

Competition in final goods markets can also affect these kinds of network relationships by putting pressure on manufacturers to obtain their components more cheaply. In a market environment, manufacturers would simply demand lower prices. In a long-term relationship, they must help their suppliers make cost-reducing process improvements to their production processes. ${ }^{95}$ Stresses of a Schumpeterian character also sometimes arise where manufacturers must engage in extensive product innovation in order to retain their customer base. Here again, in order to maintain their network advantages, they must work with their suppliers as well as engage in product development themselves. Although the costs of retooling production throughout an entire supply chain can be enormous, there are also potential advantages to be derived from being able to access the human capital and financial resources of multiple firms. ${ }^{96}$

Whether or not networks of long-term relationships, or for that matter any other type of coordination mechanism, can survive such environmental pressures is likely to vary from industry to industry and even from firm to firm, as well as with the nature and magnitude of the

\footnotetext{
${ }^{94}$ For a study of such a response in the case of the automobile industry, see Toshihiro Nishiguchi, Strategic Industrial Sourcing: The Japanese Advantage (New York: Oxford University Press, 1994).

${ }^{95}$ On Honda practice, see John Paul MacDuffie and Susan Helper, "Creating Lean Suppliers: Diffusing Lean Production through the Supply Chain," in Jeffrey K. Liker, W. Mark Fruin, and Paul S. Adler, Remand in America: Transplanting and Transforming Japanese Management Systems (New York: Oxford University Press, 1999), pp. 154-2000.

${ }^{96}$ For the automobile case, see Kim B. Clark and Takahiro Fujimoto, Product Development Performance: Strategy, Organization, and Management in the World Automobile Industry (Boston: Harvard Business School
} 
stress. Hence we come to the vital importance of maintaining a forward-looking, as well as a backward-looking, perspective on the process of economic change. And critical to this task is acknowledging, first of all, the diversity of coordination mechanisms available to firms at any given point of time and, second, the enormous uncertainty that business people face in deciding which mechanisms to choose. The case of AT\&T provides an instructive example. Until the early 1980s, AT\&T owned and operated a telephone system that was integrated both horizontally and vertically. Its subsidary Bell Operating Companies (BOCs) offered local service and interconnection to AT\&T's long distance network, and Western Electric provided the equipment from which the network was built (with the aid of research conducted at Bell Labs). Under pressure from the federal government to reduce its monopoly position, AT\&T was forced to divest itself either of its horizontal or vertical operations. Following a chain of reasoning similar to Chandler's, AT\&T's management chose to keep its vertical structure intact. The firm retained Western Electric and Bell Labs and gave up the BOCs, launching them as seven independent regional BOCs or RBOCs. ${ }^{97}$

This industry structure endured only about a decade. The new AT\&T found itself unable to compete effectively in the rapidly changing telecommunications industry, and like other large firms at about the same time, shifted toward dis-integration, spinning off its vertical operations into a variety of separate firms. Western Electric and Bell Labs were reorganized as Lucent Technologies, which itself fell on hard times by the end of the 1990s. In the meantime, AT\&T expanded (mainly by acquisition) into the wireless and broadband sectors of the telecommunications market. But, when the synergies it expected between its new and old

\footnotetext{
Press, 1991). See also Dyer, Collaborative Advantage.

${ }^{97}$ See Peter Temin with Louis Galambos, The Fall of the Bell System (New York: Cambridge University Press, 1987).
} 
activities failed to materialize or provide any competitive advantage, AT\&T again split itself up into separate firms.

The confusion displayed by AT\&T's executives was by no means unique. Other telecommunications giants have gone through similar waves of acquisition and divestiture, as have firms in other sectors of the economy. The dispute that occurred in the computer industry during early 2002 between the management of Hewlett Packard (HP) and some of the firm's largest shareholders about whether to merge with Compaq is suggestive of the high degree of uncertainty that actors on the ground have about the best way to respond to economic change. (The final vote, after months of debate and reflection, was extremely close.) Further evidence comes from the enormous numbers of international acquisitions made during the late 1990s that, a few years later, were already being divested. According to one report, fully one third of the mergers negotiated between 1996 and 1998 had been (or were in the process of being) undone by 2002. As for the chief executives responsible for the deals, about the same proportion had already been replaced. ${ }^{98}$

Mistakes continue to be made because the diversity of ways in which businesses are succeeding in new competitive environment makes it extremely difficult to predict the direction of change. Thus, at the same time as AT\&T, Worldcom, and other telecommunications giants were forced to shrink, the RBOCs were expanding by merging with one another, reducing their number from seven to four. They also extended their business from local to interstate calling and successfully entered wireless and other new telecommunications markets. Although the major trend in the steel industry during the last quarter of the twentieth century was toward vertical specialization, during the 1990s increased integration by successful newcomers like Nucor and

\footnotetext{
${ }^{98}$ The survey was conducted by KPMG Consulting. See Dan Roberts, "Survey Casts More Doubt on
} 
the resurgence of some traditional integrated producers such as Wheeling-Pittsburgh suggested that a counter trend was in the works. The symbiotic relationship in pharmaceuticals between large firms and small start-ups revealed an ongoing role for the vertically integrated enterprise in that industry as well, while the continued success of firms like General Electric (GE) served notice that the conglomerate model was by no means dead. At the same time, however, the Silicon Valley phenomenon spurred a resurgence of interest in industrial districts, and policy makers devoted an enormous amount of effort to trying to replicate this vibrant community of computer hardware and software producers in other locations around the world. Alliances between big businesses were also on the rise, accounting by 1998 for slightly in excess of 25 percent of the total revenue of the 1000 largest U.S. public companies (up from only 2 percent in 1980). Indeed these kinds of deals were roughly equivalent in volume to mergers and acquisitions by the late 1990 s. $^{99}$

We conclude by noting that nothing underscores better the difficulty of predicting the direction of change in business organizations than the annual survey of CEOs from around the world conducted by the Financial Times. The ten most respected business leaders of 2001 included people from highly focused companies such as Intel (Andy Grove) and Microsoft (Bill Gates), as well as gurus of vertical disintegration such as Hiroshi Okuda of Toyota and computer assembler Michael Dell. But it also included heads of more traditional Chandlerian firms such as Lou Gerstner of IBM or John Browne of BP Amoco. More intriguing still, nearly a third of the spots on the top ten list were occupied by CEOs of conglomerates: Jack Welch of GE, Warren Buffett of Berkshire Hathaway, and Richard Branson of Virgin. ${ }^{100}$ That business people from

\footnotetext{
Value of Mergers," Financial Times (22 Feb. 2002), p. 1.

99 J. Harbison and P. Pekar, Smart Alliances: A Practical Guide to Repeatable Success (San Francisco: Josey-Bass, 1998); and Matthew Schiffrin, "Partner or Perish," Forbes (21 May 2001), p. 26-28.

${ }^{100}$ Michael Skapinker, "Business Leaders: Admiration for Those Doing It Their Own Way," Financial
} 
around the world set up such a diverse group as role models is an important indication of the ongoing uncertainty they face about the direction of change and how to solve the coordination problems that confront them. Their uncertainty in turn should be a powerful signal to us that the shift toward long-term relationships that characterized the "new economy" of the late twentieth century should not be taken as a new ending point for American business history.

Times (17 Dec. 2001), p. II. 